\title{
OLD HELSINKI SLANG AND LANGUAGE MIXING
}

\author{
Vesa Jarva \\ Visiting Professor of Finnish Language \\ ELTE University, Budapest
}

\begin{abstract}
The study concerns itself with Old Helsinki Slang (OHS), a peculiar speech variety (spoken approximately between 1890 and 1950), mixing Finnish morpho-syntax and Swedish vocabulary. It is claimed that it resembles intertwined mixed languages. The study focuses on the lexical, phonological, morphological and syntactical features which are most likely contactbased. Besides the vocabulary, the impact of Swedish is clearly seen in phonology, while in morpho-syntax differences from Finnish are minor. In the conclusion, OHS is compared with Media Lengua and Ma'á. Although OHS was never an independent or an established system, it has a particular value as an example of language mixing in an exceptionally well-documented urban environment, even though the process was interrupted, and OHS gradually merged with Finnish.
\end{abstract}

\section{Introduction}

This paper deals with with Old Helsinki Slang, a peculiar speech variety spoken in Helsinki (approx. from 1890 to 1950), in which Finnish morpho-syntax is combined with Swedish vocabulary. ${ }^{1}$ The term Old Helsinki Slang (OHS henceforth) is translated from the Finnish vanha Helsingin slangi. The term vanha Stadin slangi 'a slang of the City' is also widely used. (A slang word stadi 'city' comes from Swedish stad 'city, town' and it is particularly used in Helsinki, and not in other Finnish towns).

OHS is strongly influenced by the Swedish language, and it differs clearly from both Standard (written) Finnish and Finnish dialects spoken at the same time. So much, that it is by some authors regarded as a language on its own. Heikki Paunonen, who did the most intensive research on OHS, characterises it as an independent and original speech form and considers it as distinct from the modern slang, or slangs, spoken in Helsinki According to him, OHS does not fulfil the criteria "commonly used in a definition of slang" (Paunonen, 2006:57). By this he probably thinks of OHS

\footnotetext{
${ }^{1}$ I would like to thank Petri Kallio, Bernhard Wälchli and the referees of the Journal of Language Contact for their invaluable comments on a previous draft of this article. The writer alone remains responsible for any remaining shortcomings, omissions or errors.
} 
as being neither just a collection of stylistically marked lexical items used interchangeably nor being used only by a certain generation or in some special field of interest.

The following example (1) illustrates typical features of OHS. A parallel sentence in (dialectal) Finnish is represented in example (2).

$\begin{array}{cllllllll}\text { (1) föra-kaa } & \text { nyt } & \text { toi } & \text { Väiski } & \text { bastu-un } & j a & \text { tvetta-kaa } & \text { se-n } & k \text { labbi- } t \\ \text { take-IMP.2PL } & \text { now } & \text { that } & \text { (name) } & \text { sauna-ILL } & \text { and } & \text { wash-IMP.2PL he-GEN } & \text { foot-PL } \\ \text { (2) vie-kää } & n y t & \text { toi } & \text { Väiski } & \text { sauna-an } & j a & \text { pes-kää } & \text { se-n } & \text { jala-t } \\ \text { take-IMP.2PL } & \text { now } & \text { that } & \text { (name) } & \text { sauna-ILL } & \text { and } & \text { wash-IMP.2PL he-GEN } & \text { foot-PL }\end{array}$

'take V. to sauna now and wash his feet'

Morpho-syntactically the sentences are so conform that they are glossed similarly. But, although there are regular Finnish grammatical endings after the noun and verb stems in example (1), the stems themselves are borrowed from Swedish: föra 'lead, carry', bastu 'sauna', tvätta [tvet:a] 'clean, wash'. These lexical items originate from Standard Swedish with identical meaning but $k l a b b$ 'foot' apparently comes from the Swedish labb 'fin, fist' (Kallio 2007).

The adverb nyt 'now' and the conjunction $j a$ 'and' are the same as in Standard Finnish. The pronoun toi 'that' is a dialectal variant for tuo in Standard Finnish, which occurs in the Finnish dialects near Helsinki. In Standard Finnish the pronoun se means 'it, that', and it should not refer to a human being. Nevertheless, in Finnish dialects it is used quite commonly that way. Väiski is a common nickname for Väinö, a Finnish male name.

Thus, it can be said that the example (1) has Swedish vocabulary and (dialectal) Finnish morphosyntax, what is typical for OHS in general.

The focus of this article is on OHS as a contact language. The purpose is to examine to what extent OHS may be considered as a mixed language, and to illustrate how it is related to different language forms spoken in Helsinki at the beginning of the $20^{\text {th }}$ century. Since OHS was gradually absorbed into colloquial Finnish, it lost its nature as a contact language, only the material produced by OHS speakers born up to 1930 is used. This limitation is based on Paunonen's distinction by which OHS is grouped with modern slang varieties not later than the 1950's. References for the examples are given in the section 'Material sources' at the end of the article. Whenever possible, a name and the year the informant was born is also given there.

In principle, OHS is assumed here to be an independent language, not a variant of Finnish. Therefore, the question whether it has 'changed' from Finnish or 'borrowed' words from Swedish is not raised. Although the most morpho-syntactic features of OHS are similar to those of modern colloquial Helsinki Finnish ${ }^{2}$, these two language forms are not compared with each other as they due to different historic periods and were not spoken at the same time. Instead, OHS is compared to Finnish and Swedish rural dialects which were undoubtedly the native languages of the first OHS speakers. It is also possible that some other variant of colloquial Finnish was spoken in Helsinki while OHS developed, but there is no data available in order to do such kind of comparison. The common morpho-syntactic properties of Helsinki Finnish and OHS have apparently developed in parallel, as they share some features with Finnish dialects. Nonetheless, we cannot rule out the possibility that at least some of the properties developed first in OHS, and were adopted then into Helsinki Finnish- when the two language forms gradually merged.

The structure of the paper is as follows: Section 2 deals with the historical background and different language forms spoken in Helsinki and provides some information necessary for the understanding of the circumstances under which the Old Slang developed. This section addresses particularly to those readers having no direct access to Finnish sources. In section 2.5, a brief survey

${ }^{2}$ In Finnish Helsingin puhekieli says 'spoken language in Helsinki'. 
of former research and documents of OHS is provided. Section 3 discusses the issue of mixed languages and summarizes two well-known examples crucial for the subsequent discussion, Media Lengua, spoken in Ecuador, and Ma'á, spoken in Tanzania. The issue of OHS, which has also to some extent been considered as a mixed language in the literature is raised in section 3 . In section 4 the lexical, phonological, and morpho-syntactical features which are most likely contact-induced are exemplified. The lexical and phonological contact features are well recognizable and illustrated in the literature. In morphology and syntax however the role of language contact is much less selfevident and the contact features represented here might also be explained by language-internal factors. The article ends with a conclusion in section 5.

\section{Historical background}

\subsection{Finnish and Swedish variants in Helsinki}

The historical conditions under which the Old Slang arose are well known. There are many reliable written sources describing Helsinki at the end of the $19^{\text {th }}$ and the beginning of the $20^{\text {th }}$ century. The cultural, political, and economic life, social relations, the size of the population, the circumstances of immigration, and proportions of speech groups are well documented. Contemporary Finnish and Swedish rural dialects are also well-known.

Helsinki was established in the Swedish-speaking coastal area of Finland, what is remarkable from a language contact perspective. Even today the countryside both to the west and to the east of the city is inhabited mostly by Swedish-speakers. The original name of the city is Helsingfors (Sw. fors 'a rapid'), which is still its official Swedish name but the Finnish name "Helsinki" is mostly used in the international context. Nowadays, Finnish is the dominant language in the city with almost $90 \%$ of population speaking it as a first language. This is mostly due to a massive migration from Finnish-speaking areas. However, no certain rural Finnish dialect can be identified being the origin of the Finnish speech form in Helsinki. Although some Swedish-speakers have opted to use Finnish, especially amongst the working class it must be mentioned, however, that there are still about 30.000 people (roughly $6 \%$ of population) in Helsinki who are native Swedish speakers.

In 1850 there were just 20.000 inhabitants of Helsinki and about $10 \%$ of them were Finnishspeakers. Finland had been part of Russian empire since 1809, but the Swedish influence on culture and administration in Finland continued as before. The bourgeoisie, civil servants, military officers, university staff, school teachers, and priests were mostly Swedish, coming from families with long urban traditions in Finland. The social and cultural life was dominated by Swedish people, although there was also an influential group of German speaking bourgeois families. Russian influence became stronger towards the end of the $19^{\text {th }}$ century (Forsskåhl, 2006:54, 58). But not only the upper class was Swedish, the majority of the working class came from neighbouring Swedishspeaking rural areas. The Swedish language had a high status and Finnish-speaking immigrants commonly switched to Swedish. There are several historical references from the 1850's that suggest that Finnish speakers were ashamed of their native language and wished their children to have a Swedish education.

The situation began to change slowly after the 1870's, when already two-thirds of immigrants originated in Finnish-speaking areas. Swedish speakers mostly lived in the centre of the town, while the Finnish speakers established themselves in the periphery, particularly in the north. The social gap between these groups was still remarkable. In 1870, 26\% of whole population were Finnish speakers, but only $6 \%$ of highest rank spoke Finnish. Nonetheless, contemporary newspapers mentioned that Finnish was heard more and more in conversations "on the streets and in social life" (Paunonen, 1995:3-5).

The official status of Finnish changed in the last half of $19^{\text {th }}$ century. In the University of Helsinki some lecturers began to use Finnish instead of Swedish or Latin and in 1850, a chair of the 
Finnish language was established. In 1863 a new language regulation was enacted, according to which Finnish had official status in administrative and juridical issues. In a national romantic spirit, many Swedish-speaking upper class people adopted the idea of "one nation - one language". Thus, they decided to use Finnish as a home language and put their children into new Finnish schools, even though they did not speak it properly. On the other hand, the other Swedish speakers wanted to keep Swedish as the only national language of Finland. The debate was called "the language struggle" (Finn. kielitaistelu, Sw. spräkkampen). However, at the end of the $20^{\text {th }}$ century, Swedish was still dominant in the upper classes, and it had hegemony in cultural, economic and municipal issues (Paunonen 1995:5-7; Forsskåhl, 2006:53-54).

The upper class debate was rather insignificant for working class people, for whom a language was not an ideological, but a practical issue. There are several references that amongst the working class, there was no juxtaposition between the language groups (e.g. Forsskåhl, 2006:54; Paunonen 2006, 51-52). Finnish and Swedish speaking workers lived in the same areas and tried to communicate, even with a limited knowledge of each others' language. Standard Finnish did not play a role in such contexts. Moreover, Standard Finnish used by the upper class was based on the literary tradition and differed sharply from Finnish rural dialects spoken by Finnish working class people.

More importantly, the city expanded rapidly after the 1870's. The population was 61.000 in 1890, and it almost trebled in 24 years. Hence in 1914 Helsinki was peopled by 170.000 inhabitants. Population growth was mostly due to the rise of the working class-population, which number reached 80.000 in 1914. Both the community and the proportion of Finnish-speakers increased considerably. Hence at the turn of the century the population was about 100.000 with equal proportions of Finnish and Swedish speakers. Ten years later the proportion of Finnish speakers was 60\% (Paunonen, 1995:8-9; see also diagram below).

Bilingualism was common in the city, hence $35 \%$ of people declared themselves to be able to speak both Finnish and Swedish in the 1900 census. The bilinguals were from both language groups: $42 \%$ of native Swedish speakers spoke Finnish, and 30\% of native Finnish speakers spoke Swedish. When the proportion of Finnish speakers grew, bilingualism became more common among Swedish speakers, but the proportion of bilingual Finnish speakers was unchanged as before. In 1920, 72\% of Swedish speakers declared themselves to be bilingual (Paunonen, 1995:11). At present, practically all Swedish speakers in Helsinki are bilingual and most of them speak Finnish at near-native level.

As the Finnish speaking population grew on a steady basis in the 20th century, the Swedish elite lost its dominance during the course of time. Standard Finnish strengthened its position after the independence of Finland in 1917, when both Finnish and Swedish were established as official languages of the country. Compulsory education and free elementary school were in principle decreed in the constitution in 1919. In practice, an elementary school system was introduced by law in 1921. Thereafter, all Finnish speaking children, including such from the lower classes, were educated in Standard Finnish but Swedish speaking children still attended their own schools. This was a remarkable turn. There had been free schools classes for all children even earlier, but they were voluntary and most working class children started to work as early as possible. Under the old system, both Finnish and Swedish speaking children were at first in mixed schools, and after the first two or three classes they went to the Swedish schools in the city centre (Forsskåhl 2006, 62). 


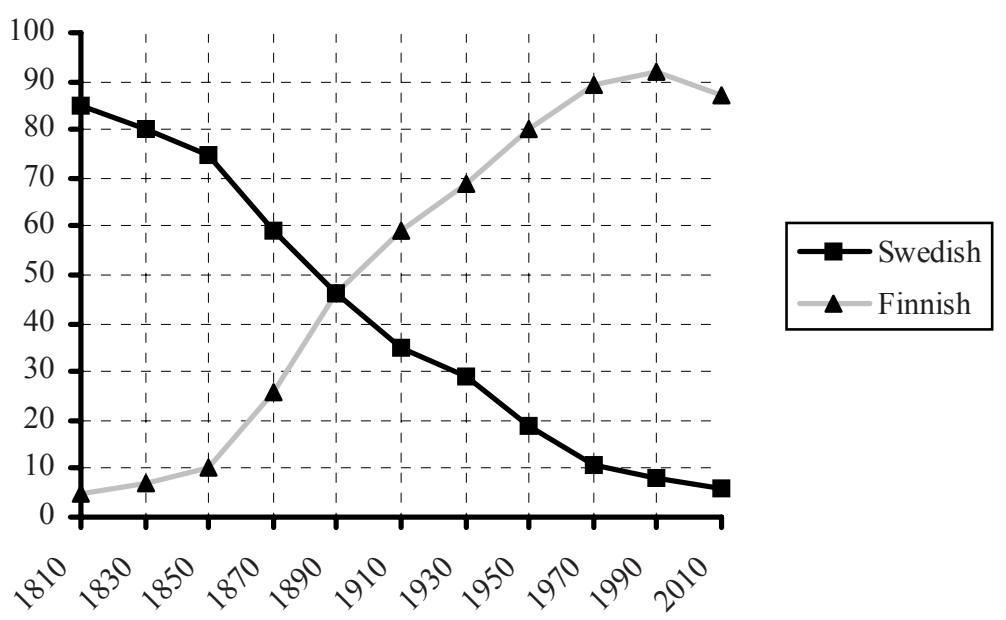

Figure 1: Proportions of people speaking Swedish and Finnish as native language in Helsinki. Minor language groups (Russians, Germans, etc.) are excluded for clarity. (Kallio, 2007.)

\subsection{The birth of Old Helsinki Slang}

There are several references to the fact that OHS was born at the end of the $19^{\text {th }}$ and the beginning of the $20^{\text {th }}$ century in rapidly growing bilingual working class areas. It was first registered from the 1890's, in a time of rapid industrialization, when new working class areas emerged in the north of the old town, namely Kallio, Sörnäinen, Hermanni and Vallila (Sw. Berghäll, Sörnäs, Hermanstad and Vallgård). In the year 1900, 20.000 people were already living in the northern districts, two thirds of them being Finnish-speakers. The crucial precondition for the birth of OHS was, that "there was a tolerant attitude towards different languages and there was a balance between Finnish and Swedish" (Paunonen, 2006:52). The Finnish speakers were in the majority, but Swedish was far more prestigious, and it already had an established position in Helsinki, while Finnish speakers were mostly newcomers.

As mentioned above, the "language struggle" between Finnish and Swedish was only an upper class phenomenon. In the working class areas, Finnish and Swedish speaking families lived side by side in the same houses and the same apartments. Marriages between the language groups were common, although husbands and wives in many families could not understand each other properly if at all. As the immigrants did not speak standard Finnish or Swedish but various dialects, their children became bilingual with two dialects (Forsskåhl, 2006:63). On the community level there was functional bilingualism with people using Finnish and Swedish.

Slang was first spoken by boys and young males in gangs on the streets; as there was no compulsory education system and the apartments were small and crowded, working class children spent most of their time outdoors, out of grown-ups' linguistic models and control (Forsskåhl 2006, 63). The Finnish word for these gangs was saki 'gang, mob, group', and OHS was called as sakilaisten kieli 'gang people language', sakin kieli 'gang language' or just saki.

The identity of saki gangs was based on their own street or part of the city and not on the native language; thus there were both Finnish and Swedish speaking boys in the same gangs. OHS was even romantically called "Esperanto in Helsinki", pointing out that it was essential for communication in these bilingual groups (Paunonen, 2006:51). As OHS was created by dialect speakers, it has its origin mostly in Swedish and Finnish dialects. 
Nonetheless, OHS did not arise out of communication needs alone, but it represented also an important marker of group-identity. Although Swedish-speaking immigrants came from the countryside, the Swedish language itself had long established roots in the city, whereas Finnish speakers did not have any urban traditions. For them, the city was a 'melting pot', where the young were trying to establish their identity, including a linguistic one. In $1910,30 \%$ of the population in Helsinki were Swedish speakers, but among those born in Helsinki, the proportion of Swedish speakers was 51\% (Paunonen, 1995:8).

Considering the fact that Finnish speakers were in the majority, it is surprising that OHS vocabulary is so overwhelmingly Swedish. For example, most terms used in outdoor games are of Swedish origin. It is assumed that the vocabulary had been absorbed from older 'street boy' slang or a dialect of Swedish (Paunonen, 2006:52). This is possible, but it is still a hypothesis, as we have no documents of such a variant of Swedish. But Swedish schoolchildren and students had a slang on their own, which has been documented somewhat earlier than OHS and has apparently roots going back a long way. Forsskåhl (2006:58) even states that this 'inner city slang' "dated back, in part, to at least to the days when the first university was established in Finland in the $17^{\text {th }}$ century".

Despite the social gap, the Swedish inner city slang has undoubtedly impacted on OHS, what is observable in the common words of these two language forms (see section 2.3). It is possible that the old school system, where Finnish and Swedish children were at first together in mixed schools and later attended schools in the town centre, has provided a link. In the 1910's many slang words spread rapidly to both language groups, and there might be both Finnish and Swedish sources for a slang word from exactly the same time (see friidu $\sim$ fridon 'girl' and kundi $\sim$ kunden 'boy' in section 3.3). It is of note that the common vocabulary is mostly of Swedish origin, with some Latin, German, and Russian words; there are Finnish words in OHS but in Swedish slang there seems to be none. Only after 1920 did Swedish speakers start to import words from Finnish (Forsskåhl, 2006:60, 62).

OHS had a low status, as it was socially stigmatized 'street boy language', and in upper class families children were not allowed to speak it. As it mixed Finnish and Swedish, OHS violated the national romantic idea of a 'pure language', and it did not follow the rules of Standard Finnish taught in the elementary schools. Therefore, school teachers took a negative attitude towards OHS. In the class room, schoolchildren were forced to speak Standard Finnish, and some teachers even blamed children for speaking OHS during the breaks (Paunonen 2000:42-43).

Although OHS implied a strong working class identity, it was neither spoken nor even accepted in all working class families. Mothers in particular depreciated it, as they did not understand OHS and considered it as to be a gang language. Some slang speakers reported that their mothers did not accept the slang word mutši 'mother'. (Paunonen, 2000:43.) The word is an OHS innovation; the first part reminds us of the Swedish mor, moder [mu:r, mu:der] 'mother', and the ending -tši is a socalled slang suffix with no specific semantic content (see section 4.2). The standard Finnish word for 'mother' is äiti.

Fathers took a more positive attitude, as some of them were OHS speakers themselves. According to Väinö Salomaa (born in 1910): "My mother was angry: "Why do you speak such an awful language?" My father said: "What are you talking about, our son speaks a foreign language, for God's sake!" (Paunonen, 2000:43).

\subsection{The language forms with an effect on OHS}

OHS did not only arise as a mixture of two languages, as both Finnish and Swedish languages spoken in Helsinki were not homogenous, even though they had standard forms. Written Standard Swedish does not vary in any significant way in Sweden and Finland, although there are minor differences in vocabulary. Yet pronunciation is rather different in Swedish spoken in Sweden (Sw. 
rikssvenska, Finn. riikinruotsi) and in Finland, where a variant of Swedish spoken in Helsinki is called 'Finland Swedish' (Sw. finlandssvenska, Finn. suomenruotsi). Some features of Finland Swedish are presumably due to contacts with Finnish: for example, unstressed consonants are pronounced long (veta 'to know' and läsa 'to read' are pronounced [ve:t:a] and [le:s:a]. This reminds us of Finnish, where all consonants and vowels are in quantitative opposition. It is also said that Finnish and Finland Swedish have such similar intonation that if you are not close enough to understand the words, you cannot hear it if people are speaking Finnish or Swedish in Helsinki (Höckerstedt, 2006:129).

Both Standard (Finland) Swedish and Standard Finnish had a limited influence on uneducated OHS speakers, although they probably had more contacts with Standard Swedish than Finnish, especially at the time when OHS was born. Standard Swedish had a long literary tradition in Finland stretching back hundreds of years. It was commonly spoken by the upper class and was used by the authorities, and it had established position in the city. Standard Finnish (kirjakieli 'written language') was just developing as a modern language applicable in all domains; traditionally it was mostly used only in religious texts. It was unfamiliar for most Finnish speakers, not to mention Swedish speakers. The Finnish speaking working class had a steady access to Standard Finnish only through the elementary school system in the 1920's, when OHS was already widely used. On the other hand, it is not always possible to distinguish whether a particular word is based on a dialect or standard language, as many OHS words are manipulated (see sections 4.1 and 4.2).

For OHS speakers, rural dialects were the most familiar form of Finnish. ${ }^{3}$ At the beginning of the 20th century, almost all Finnish speakers had a rural dialect as a native language; as did the immigrants moving to Helsinki. At first, the immigrants came from the neighbouring areas, Uusimaa and Southern Häme. The Finnish dialects of these areas had some features apparently detectable in OHS. For example, a special 'slang verb conjugation' illustrated in section 4.4. has its origin in Finnish dialects spoken near Helsinki (Paunonen, 1995:13). At the later stage of immigration, more people speaking various dialects came from further away. As the dialectal background of Finnish speakers was heterogeneous and dialects were considered as country speech, no single dialect could be a foundation for OHS and urban identity. Nonetheless, almost all morpho-syntax in OHS is based on Finnish dialects. When this is not the case, it is mostly due to innovation in OHS (see sections 4.4 and 4.5).

One feature apparently based on Standard Finnish in OHS is the voiced stop $d$, which is unknown in Finnish dialects. In the western Finnish dialects, $r$ occurs instead of $d$, and this had been common also in OHS until the 1920's (Paunonen, 2005:40). However, there are several examples of $d$ in OHS, as it follows:

$\begin{array}{rllllll}\text { (3) Sit } & k u & m \ddot{a} & \text { ol-i-n } & \text { yhde- } n \quad \text { vuode- } n & \text { dilkka-nu } & \text { Svenska Presseni-ä... } \\ \text { Then } & \text { when } & \text { I } & \text { be-PAST-1SG } & \text { one-GEN year-GEN } & \text { deliver-PARTCP } & \text { name-PART }\end{array}$

'then, after I delivered Svenska Pressen (Swedish newspaper) for one year...'

This sentence is morpho-syntactically genuine (dialectal) Finnish, and the lexicon is also Finnish, apart from the OHS verb dilkkanu and the Swedish newspaper name Svenska Pressen 'Swedish Press', which has a regular Finnish partitive case ending. The verb dilkkaa 'deliver' is apparently Swedish (cf. Standard Swedish dela 'deal'), and hence the initial $d$ is fully expected, but in the Finnish words yhden vuoden the $d$ comes from Standard Finnish; the dialectal form should be yhren vuoren. It is possible that the OHS speakers have begun to conceive the dialectal $r$ as being too rural, and the $d$ is also incorporated into Finnish words without any effort, as this sound occurs also in Swedish words.

\footnotetext{
${ }^{3}$ Finn. suomen murteet; a word murre 'dialect' coming from a verb murtaa 'to break'.
} 
Swedish speaking immigrants spoke various Finland Swedish dialects (Finn. suomenruotsin murteet, Sw. finlandssvenska mål or östsvenska mål 'east Swedish dialects'), which might be very different from Finland Swedish spoken in Helsinki. Many lexical items of OHS may be traced back to Swedish dialects, mostly to those spoken in the neighbourhood. For example, words dokaa 'drink (alcohol)', duuni 'work', bisse 'old man' and kloddi 'child' originate in the dialect of Sibbo (Finn. Sipoo), a Swedish-speaking rural area just east of Helsinki. (Paunonen 2000:29). The phonology of the Sibbo dialect fits well into the Finnish system, which may be one reason why it is so frequently exploited in OHS (Forsskåhl, 2006:65). A few words can be traced back to more distant Swedish dialects.

In the example (4) both duuni and kloddi originate from the Sibbo dialect. Mutši 'mother' is an OHS innovation, as mentioned above; fatši 'father' is respectively composed from (Standard) Swedish far, fader 'father' and the slang suffix -tši. Although it is apparent that these words have their origin in Swedish, it is not possible to indicate whether they came from standard language or some local variant. Other words are Finnish by origin (numeral viis 'five' is viisi in Standard Finnish), and morpho-syntactically the sentence is genuine Finnish.

\begin{tabular}{|c|c|c|c|}
\hline & $\begin{array}{l}k \ddot{a} \nu-i \\
\text { go-PAST-3SG }\end{array}$ & $\begin{array}{l}\text { duuni-ssa } \\
\text { work-INE }\end{array}$ & $\begin{array}{l}j a \\
\text { and }\end{array}$ \\
\hline
\end{tabular}

'[we did not have money:] father and mother were working, but there were five kids [in the family]

Furthermore, the Swedish inner city slang or some other colloquial variant of Swedish can be detected in OHS. Forsskåhl (2006:59) lists several Swedish inner city slang words, which are used in OHS: vippa (OHS vippaa) 'lend, borrow', krabbis (OHS grabbis, krabbis) 'hangover', gåsis 'school caretaker' (OHS gosis, kosis) 'caretaker', funtja (OHS funtsaa, funtšaa) 'think, ponder', skäta 'hit on somebody' (OHS skotaa). Some Latin and German words are among these words as well, and many are obviously imported from Sweden, from Uppsala and Stockholm schoolchildren and student slang.

An interesting parallel for OHS is the so-called Kitchen Finnish a variant of Finnish heavily influenced by Swedish. ${ }^{4}$ It was used as an intermediate language between Finnish service staff and Swedish masters and employers. The idealistic users of Standard Finnish considered Kitchen Finnish as 'vulgar' or 'impure', but it was still used for practical reasons even in the purest of households. It was said that 'the boundary of pure Finnish went between the living room and the kitchen'. (Paunonen, 2006:60.) It is possible that Kitchen Finnish contributed Swedish words to OHS, especially the naming of household accessories and groceries. There was heavy Swedish interference in Kitchen Finnish syntax, and thus it resembles a variant of Finnish as a second language learned by Swedes; and some peculiarities in OHS syntax may have their roots in Kitchen Finnish or L2 Finnish (see section 4.5).

The Russian language has also had an impact on OHS, as until 1917 Finland was a part of the Russian empire and many Russian civil servants and soldiers lived in Helsinki. More Russians followed the army or came as seamen or traders (Forsskahl, 2006:54-55). Boys were interested in Cossacks and their horses, and they accompanied soldiers and visited garrisons. Russian soldiers sold food, especially bread to civilians. As many Russian families lived in working class areas, it is natural that saki gangs had contacts with Russian children. (Paunonen, 2005:53.) In OHS there are around a hundred Russian words, for example djengi (< déngi) 'money', safka 'food' $(<$ zavtrak 'breakfast'), and mesta (< mésto) 'place'. Some Russian words were also known in Swedish inner city slang, as snaja (OHS snaijaa) 'to understand' (< znaj- 'to know'), lafka < lávka '(small) shop' and kurva (< kúrva) 'whore'. (Forsskahl, 2006:61). The Russian influence ceased drastically soon

\footnotetext{
${ }^{4}$ In Finnish kyökkisuomi; kyökki is borrowed from Swedish kök 'kitchen', whereas a Standard Finnish word for 'kitchen' is keittiö.
} 
after the independence of Finland, when Russian civil servants and soldiers left the city.

The English language had only a minor influence on OHS, although it has given a multitude of words to modern slang variants since 1950's. Still, there are some English words, which had apparently come from films (cinemas were common and relatively cheap even in 1910's) or by sailors. English words in OHS are e.g. indari $\sim$ inkkari $(<$ Indian $)$, koobari $\sim$ goobari $\sim$ skoobari $\sim$ skoopari $\sim$ skoubari (< cowboy), šeriffi seriffi 'police' (< sheriff), dongarit 'jeans, overalls' $(<$ dungarees); faini $(<$ fine), knaiffi $\sim$ naiffi $\sim$ knaiffe $(<$ knife) and tšali $\sim$ tsali 'boy, young man' $(<$ Charlie) (Paunonen, 2000:31).

\subsection{OHS and modern slang variants in Helsinki}

As more and more people emigrated from Finnish-speaking areas to Helsinki, OHS lost its function as an intermediate language between Finnish and Swedish speakers. Newcomers had no more need to neither understand nor speak Swedish, as Finnish speakers were in the overwhelming majority and Swedish speakers became bilingual. Furthermore, a language shift from Swedish to Finnish was common in the working class. OHS preserved its status as an urban marker of identity, but saki gangs became more and more often monolingual Finnish. During World War II the tradition of saki gangs was broken, as young men (even 17 years old could be recruited as volunteers) got into the army and boys were often moved to the country for months, due to frequent bombings and the lack of food in the city.

These factors affected the slang in such a way that the Old Slang lost many of its contact-based properties and only gradually developed into the modern slang, at least this was true of the 1950's. The modern slang is based much more on Finnish: for example, the affricate $t \check{s}$ changed to the consonant cluster $t s$, morpho-syntax became identical with Colloquial Finnish and the amount of the words originating in Finnish increased. More and more words were borrowed from English.

At the same time, Swedish slang developed in its own way, and the direction of borrowing changed: more and more Finnish vocabulary and Finnish variants of OHS words were used in Swedish slang. At present, Finnish words are frequently used in Swedish slang and code-switching is more a rule than an exception (Saari, 2006).

As is true of slang in general, modern Helsinki slang is not connected to a certain street or a part of a town, but to the whole generation, youth culture, or a special life style or field of interest. It has also lost its working class status. At first, modern Finnish slang spread to the whole city and then outside of it. Due to the prestige status of the capital, modern slang varieties are commonly used in the mass media and they spread throughout the whole of Finland. Thus, it is difficult to separate out modern slang from colloquial speech. The modern slang variants merge with present Helsinki Finnish, even though they have maintained some special features of the Old Slang. For example, a few Russian words, which were definitely borrowed up to 1917, have established their position.

\subsection{Former research and documents of OHS}

The first mention of OHS in writing is from the year 1890, when the novelist Santeri Ivalo wrote a short story Hellaassa, which is about a first year university student. ${ }^{5}$ There are such words in the short story as aasis 'institute of anatomy' (cf. to a Swedish adjective anatomisk), Studis ( $<\mathrm{Sw}$. Studentshuset 'Students' house') and labbis 'laboratory' (< cf. Sw. laboratorium, Finn. laboratorio). These words stem apparently from (Swedish) university students' slang, but they reflect the same strategy of manipulating words as in OHS: they have a Swedish beginning or 'stem' and a slang suffix -is. Aside from the separate slang words, the whole story is written in Standard Finnish (Paunonen, 2000:40).

In the beginning of the $20^{\text {th }}$ century, Finnish humorous magazines called Kurikka and Tuulispäa

\footnotetext{
5 "In the Hellas", the name does not refer to ancient Greece but to an pub in the outskirts.
} 
published stories and chats with more or less OHS words, sometimes even morpho-syntactical features. In 1915, the alias Sakinkielen professori "professor of Saki language" described OHS as follows

"Like in big foreign cities, in Helsinki saki people also have a language of their own. It is not entirely perfect, but it has to be spoken with Finnish or Swedish. 15 or 20 years ago, this saki language of Helsinki was used only by little boys selling newspapers. - - [Later] the vocabulary of the little boys was transferred to the adult generation, and numerous new words were born. - - It is not a harmonious language, but it is good enough for honoured saki people."

The author gives the following example:

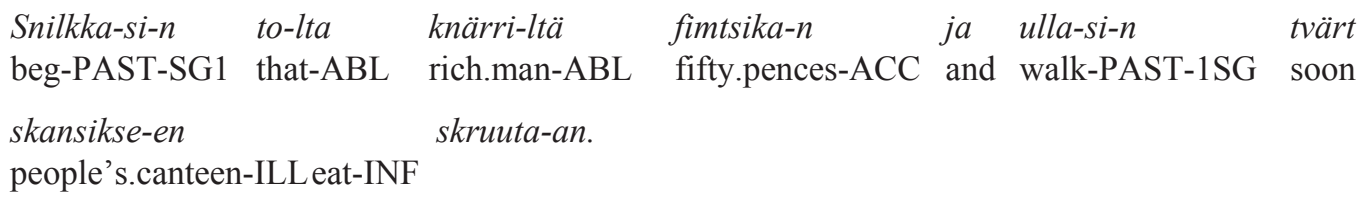

'I beg fifty pence from that rich guy and walked soon to a people's canteen for a meal'

In this sentence, apparently constructed by the 'professor', we may find some most typical features of OHS. It has Finnish grammar and some Finnish dialectal forms, but the vocabulary consists of peculiar 'Un-Finnish' words from different origins. There are also some typically manipulated words. In Standard Finnish, a parallel sentence could be as follows:

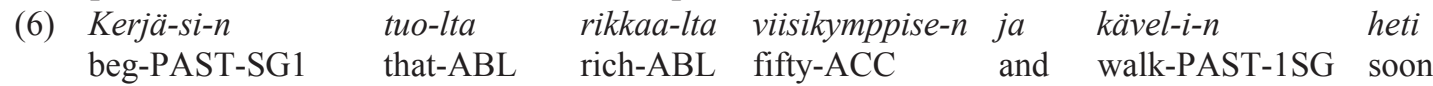

kansanruokala-an syö-mään.

people's.canteen-ILLeat-INF

The only word from Standard Finnish is the conjunction $j a$ 'and'. The pronoun tolta is dialectal Finnish (ablative form of toi 'that', see the first example). The parallel word in Standard Finnish is tuolta. Moreover, two words seem to be manipulated forms of Finnish words. Dullaa 'to walk' is probably a variant of the more common OHS word dallaa 'walk', which originates from the Finnish tallaa- 'tread, trample, stomp'. Skansis (inflectional stem skansikse-) comes from the Standard Finnish kansanruokala 'people's canteen'. Both the voiced stops and word-initial consonant clusters are typical of OHS and, as they are not found in most Finnish dialects, they are typically used instead of unvoiced stops $(d<t)$ or single consonants $(s k-<k$-) in the order of making words more 'slangish'. (See sections 4.2 and 4.3.) In skansis a slang suffix -is is once again used.

All other words are Swedish or of unknown origin. Tvärt 'soon' is known in Standard Swedish. Fimtsika 'fifty' is manipulated from the Swedish femtio; -tsika is a slang suffix, as -is above. Skruutaa 'to eat' comes from the Swedish skrota, originating in Stockholm slang. Snilkkaa 'to beg' and knärri 'upper class boy, rich man, dandy' are of unknown origin. Phonologically they seem to be Swedish, but this does not mean very much, as they may well be manipulated in the same way as dullaa and skansis.

Grammatically this sentence is genuine Finnish, although it is possible that the syntax is "improved", which is characteristic of early OHS sources (Kallio, 2007). For example, there should be presumably a personal pronoun mä (in Standard Finnish minä) before the predicates snilkkasin and dullasin. Omission of a personal pronoun is typical for written Standard Finnish. In any case, there is a dialectal infinitive form skruutaa-n (which should be *skruutaa-maan according to Standard Finnish rules).

In the 1910's and 1920's several novels were published, that used OHS words in their dialogue. 
Here Katupoikia ('Street boys') should be mentioned by O. Malmberg (1915) and Kadun lapsia ('Street children') by T. Tarvas (1920). E. Salola's novel Ilman fritsaria was published in 1929, and it also includes a word list. ${ }^{6}$ In 1915 OHS was heard even in the Finnish National Theatre, when the Cockney spoken by Liza was translated to OHS in G. B. Shaw's Pygmalion (Paunonen, 2000:40). Since then, Helsinki slang has been commonly used in fiction and memoirs, and there are several "tongue-in-cheek" slang translations of comics, Finnish literature classics, the Bible etc. The problem concerning these modern slang texts is that OHS can not be distinguished from modern slang expressions (Kallio, 2007).

Helsinki slang has, for the most part, been investigated lexically, and there have been word collections since the beginning of the $20^{\text {th }}$ century. In 1914, a list of about 400 OHS words compiled by E. Meriluoto was published in Kurikka under the name Sakilainen sanakirja ("Dictionary of Saki") (Paunonen, 2000:40). A word list collected in the late 1920's by Y. Z. Wichmann consists of almost 500 words. The most remarkable OHS word collections are made by T. Kaiponen, K. Linna and K. Stenvall; each of them contains about 3000 words from 1915 to the 1940's. Very few recordings or notes of Old Helsinki slang were made from free speech. Most notable is a discussion of four OHS speakers (born 1899-1905), recorded by M. A. Numminen in 1965. The word collections and recordings are mostly held in the Research Institute for the Languages of Finland (Kotimaisten kielten tutkimuskeskus) in Helsinki.

The scholar who did the most intensive academic research on OHS is Professor Heikki Paunonen, who has co-edited (with Marjatta Paunonen) a dictionary of Helsinki slang (Paunonen, 2000). The dictionary compiles practically all available material sources of OHS. It has 33.000 entries, including names of persons and places, and it also gives plenty of examples. There are both OHS and modern slang words in the dictionary, but it has references to source material and also gives a period when each word was used. Therefore it draws a clear picture of OHS vocabulary. The material used in this paper is mostly collected from Paunonen's dictionary.

The overwhelming majority of OHS material is collected by laymen, as linguistic research in Finland traditionally focused on rural dialects. Urban speech forms were ignored till the 1970's, when sociolinguistic research projects were begun. Paunonen participated in a project researching colloquial Finnish speech in Helsinki from its beginning in 1972 (the results are reported in Paunonen, 1995). The project did not concentrate specifically on OHS, but it illuminates its background, as it examines historical and sociological circumstances and different speech forms at the very same time as when OHS was developing. Paunonen has written several articles about OHS mostly in Finnish; the most significant are an introduction to the dictionary of Helsinki slang (Paunonen, 2000:14-44), and an article Vähemmistökielestä varioivaksi valtakieleksi 'From a minority language to a dominant language with many varieties' (Paunonen, 2006).

\section{Mixed Languages}

The concept of a mixed language has been defined in several ways, and there is no consensus as to which languages should be considered mixed. In general, it may be said that a mixed language has more than one source of its lexicon and morpho-syntax. Although one component may be adopted from one source language without remarkable changes, a mixed language as a whole system is unlike all of its source languages. This means that a mixed language cannot be classified into the traditional genealogical trees (Bakker, 1996:13).

In addition to creoles and pidgins, there are several languages considered mixed by many scholars. These languages have two source languages, and they are created by ethnic groups for expressing their identity and differentiate themselves from the speakers of the source languages (Bakker, 1996:18). Bakker (ib.) calls them 'intertwined languages', Thomason (2001) calls them

\footnotetext{
6 'Without a stamp'; fritsari is an OHS word from Swedish frimärke 'stamp'.
} 
'bilingual mixtures' or 'bilingual mixed languages'. Such languages may be roughly divided into two groups: there are languages, which have lexicon from one source and grammar from the other, and there are languages, which have two sources for their grammar. In the first group, well-known cases are the Media Lengua (Spanish lexicon and Quechuan grammar) and Ma'á (Cushitic lexicon and Bantu grammar). In the second group there are languages such as Michif, mixing French and Cree grammar, and Mednyj Aleut (Copper Island Aleut), mixing Russian and Aleut grammar (E.g. Thomason, 2001).

It is especially the languages, which show a dichotomy of the lexicon and the grammar, such as Media Lengua, which have a controversial status as mixed languages. Some scholars consider them to be even characteristic mixed languages, while some others do not qualify them at all. McConvell \& Meakings (2005:12-13) have discussed the issue further. They have collected some common criteria for mixed languages in a table, which indicates whether Michif, Media Lengua and Gurindij Kriol (mix of English based creole and traditional language spoken in Northern Territory of Australia) meet these criteria. According to them, Media Lengua is not at least a prototypical mixed language, since it meets only five or six of the eleven criteria; on the other hand, Michif and Gurindji Kriol meet all of them.

As an even superficial overview shows, OHS resembles this controversial group of mixed languages. Therefore, in the following subsections Media Lengua and Ma'á will be discussed in more detail; they also are the languages compared to OHS by Wälchli (2005).

\subsection{Media Lengua}

Media Lengua is a mixed language spoken around the town of San Miguel de Salcedo, about $100 \mathrm{~km}$ south of Quito, Ecuador. It combines Spanish vocabulary (about 90\%) with Quechua phonology and grammar, using mostly Quechua derivation and inflectional suffixes. Media Lengua seems to have developed among migrant Indian construction workers around 1900-1920. The language was discovered by Pieter Muysken (e.g. Muysken, 1981:52-68). Thereafter, it has become widely known as an example of a mixed language and it is introduced in many text books.

Although there are no descriptions or other documents about Media Lengua's history, it is rather obvious that the language has developed among Quechua speakers. The language is spoken on the fringe of a Quechua speaking area, the speakers are Indians, and the older people in the community were monolingual Quechuan speakers (Bakker, 1996:15). Thereby, the original Quechuan vocabulary has changed to Spanish vocabulary. Muysken uses a term relexification and defines it as "the process of vocabulary substitution in which the only information adopted from the target language in the lexical entry is the phonological representation" (Muysken, 1981:61). Put more simply, "Spanish" words of Media Lengua have Quechuan semantics and collocations, only the phonological shape is replaced by a Spanish word with roughly the same meaning. For example, a word sinta- (from Spanish sentar 'set') which means 'sit, live, be, at, there is' exactly like tiya- in Quechua and is used in exactly the same constructions.

Media Lengua seems to be an established language, as it has native speakers and also speakers with Quechua and Spanish as first languages. The language is rather straightforward, albeit extreme in a way it has systematically replaced almost all of its content words from Spanish. Such a massive borrowing requires a good knowledge of a source language, and it is presumed that bilingual speakers were crucially involved in the emergence of Media Lengua. Presumably, the language did not arise only out of communication purposes, but rather satisfied the need for self-identification. (van Coetsem, 2000:245.) Media Lengua speakers have their own identity, coinciding neither with Spanish nor Quechua. 


\subsection{Inner Ma’á (Mbugu)}

Ma'á, spoken in the Usambra mountains in Tanzania, has traditionally been referred to an independent language with Bantu grammar and much Cushitic lexicon (e.g. Thomason \& Kaufman, 1988:223, Bakker, 1996:15). Recently, field work done by Maarten Mous has revealed that two overlapping varieties exist in the community; they are referred to as 'Normal' and 'Inner Ma'á/Mbugu' by the speakers themselves. The former has Bantu grammar and lexicon and it is closely related to the Bantu language Pare. The latter has the same Bantu grammar, but a non-Bantu lexicon, mostly of Cushitic, and it is known in the mixed language literature as Ma'á (Mous, 2003). It has been disputed as to whether the Normal and Inner Ma'á are independent languages or two registers of the same language. When Mous (2001:13-14) introduces a concept of paralexification, "the process by which a parallel word is formed for one and the same lexical entry, while sharing meaning and morphological characteristics", he uses Ma'á as an example and states that there is just one language sharing one grammar but a double, parallel lexicon.

There are only some clans tending to speak only Normal Ma'á, but mostly the Ma'a people are bilingual and use both languages fluently. In many families Inner Ma'á is the unmarked choice and it can be used for all topics of conversation. When speaking Inner Ma'á, speakers maximize the use of non-Bantu lexemes which may make up over ninety percent of speech. (Ib.)

As already mentioned, the lexicon of Inner Ma'a is mostly of Cushitic origin, but there are also words from Maasai, words with unknown origin, and manipulated Bantu words. A number of Inner Ma'á words are derived from Normal Ma'á words by changing the final vowel and the tone pattern: there is nzimé from Normal Ma'á nzima 'old man' and mnyawé from mnyáwu 'cat' (Mous, 2003:13). In some cases phonology differs in the two languages, e.g. words containing $h l$, $x$, or a glottal stop, are restricted to Inner Ma'á (Meyers-Scotton, 2002:267). There are also some nominal endings characteristic of Inner Ma'á nouns: -éCo, -éno, -éto etc. The same endings can also be used to derive Inner Ma'á nouns from Normal Ma'á nouns, such as ilambéno < ilámba 'bananabark'. The endings or "formatives" might be related to Cushitic plural suffixes. (Mous, 2003:68-69.)

In their survey, Thomason \& Kaufman (1988:228) come to the conclusion that Inner Ma'á has developed by "massive borrowing from a Bantu language into a (minimally) maintained Cushitic language". Mous (2003:213) agrees that the original language was Cushitic, although he does not considers it as the result of borrowing but as language shift. In any case, the Ma'á people have a distinct cultural identity, and they have not assimilated the culture of their Bantu-speaking neighbours. Thus, the Inner Ma'á lexicon is also a marker of a specific cultural group identification.

Therefore, Inner Ma'á and Media Lengua represent the opposite diachronic development according to Mous: Inner Ma'á has maintained its original Cushitic lexicon, but the 'outsider' language (Bantu) is the source of the morphosyntax; Media Lengua has maintained its original Quechuan grammar while the 'outsider' language (Spanish) supplies the lexicon (Myers-Scotton, 2002:271). While Media Lengua has developed by relexification, it has just one vocabulary; but in Inner and Normal Ma'á there are parallel lexicons as a result of paralexification.

\subsection{OHS as a contact language in former literature}

In the former literature, OHS has mostly been described lexically, and it has been considered at least implicitly as a variant of Finnish. Its nature as a contact language or comparisons with mixed languages is rarely considered. Unusual vocabulary of OHS has attracted attention, but it is mostly interpreted as a result of massive borrowing. Recently, Helsinki slang has been discussed from the perspective of language contacts by Bernhard Wälchli (2005, unpublished paper) and Petri Kallio (2007). Mona Forsskåhl (2006) has made some notable comments upon OHS as a contact language, albeit her main target is in research of Swedish Slang in Helsinki.

Paunonen stresses in several papers that OHS is an independent form of speech and it should not 
be considered as a Finnish slang variant. He uses the Finnish word sekakieli, which may be translated "mixed language". Nevertheless, he does not necessarily refer to the linguistic term (which has no established Finnish equivalent). Paunonen describes OHS also as a lingua franca and the "Esperanto of Helsinki"; the latter is a contemporary description from the beginning of $20^{\text {th }}$ century. By these terms he points out that OHS was used as a common language and it was essential for communication in bilingual groups. He also uses a term "matrix language" stating that dialectal Finnish was a matrix language, to which "vocabulary adopted from Swedish boys was inserted" (Paunonen, 2006:51, 57).

All the naming and terms mentioned above, albeit not explicitly connected to a linguistic concept of mixed language, confirm that Paunonen considers OHS as a separate language, which was neither Finnish nor Swedish but something in-between.

According to Paunonen, both Swedish and Finnish speaking members of the gangs had a common vocabulary, and only the grammar revealed which of the languages was a speaker's native language but even that cannot be proved conclusively in every case. This is a fascinating statement, but there is not much evidence for it. It has been illustrated by a following pair of sentences, apparently composed by Nyholm 1988. The upper one (6) has Finnish, and the lower one (7) Swedish grammar (Paunonen, 2000, 16; Kallio, 2007).

\begin{tabular}{|c|c|c|c|c|}
\hline $\begin{array}{l}\text { friidu } \\
\text { girl }\end{array}$ & $\begin{array}{l}\text { oli } \\
\text { be-PAST3SG }\end{array}$ & $\begin{array}{l}\text { redi, } \\
\text { nice }\end{array}$ & $\begin{array}{l}\text { kundi } \\
\text { guy }\end{array}$ & $\begin{array}{l}\text { dorka } \\
\text { crazy }\end{array}$ \\
\hline $\begin{array}{l}\text { frido- } n \\
\text { girl-DEF }\end{array}$ & $\begin{array}{l}v a \\
\text { be-PAST }\end{array}$ & $\begin{array}{l}\text { redi, } \\
\text { nice }\end{array}$ & $\begin{array}{l}\text { kund-en } \\
\text { guy-DEF }\end{array}$ & $\begin{array}{l}\text { dårka } \\
\text { F crazy }\end{array}$ \\
\hline
\end{tabular}

In these grammatically simple sentences the matrix language manifests itself as a Finnish verb form oli in example (6) and as the Swedish verb form va (Standard Swedish var) and Swedish definite suffixes in example (7). Common vocabulary is of Swedish origin: friidu $\sim$ frido cf. Swedish female name Frida; redi $\sim$ redig < Colloquial Swedish redig 'fair, just' (in Standard Swedish 'clear, lucid'); kundi kunden < Swedish kund 'customer'; dorka dårka cf. Swedish dåre 'crazy'. (Kallio 2007.) It should be noticed, however, that the words are not simply imported from Swedish as such, but they are OHS words with Finnish and Swedish variants. The four words are apparently of Swedish origin, but it is uncertain if they are OHS innovations or if they had first developed in some variant of Swedish. The Finnish forms friidu and kundi and the Swedish forms frido and konde are from exactly same period, before 1910 (Forsskåhl, 2006:60).

Considering the fact that examples (6) and (7) do not go back to free speech, but illustrations made by a researcher, it is questionable if separation between 'Finnish' and 'Swedish' slangs had been such distinct. As many OHS speakers were bilingual, it might be more appropriate to talk about code-switching than parallel Finnish and Swedish slangs. In any case, more accurate research of contemporary Swedish slang variants - or OHS spoken by monolingual Swedish boys - is needed. It is interesting that according to Forsskåhl (2006:60) slang words moved back and forth between Finnish and Swedish. She calls this phenomenon as "ping-pong-loaning". She also notices (ib:63) that Finnish speakers might take "any Swedish words they knew" and adapt them to Finnish morphology and phonology. These notions suggest that there has been code-switching between Finnish and Swedish.

Despite the fact that his paper is an unfinished sketch and does not separate OHS from modern slang variants, Wälchli (2005) comes up with some basic notions. He is probably the first scholar who has discussed OHS in contact linguistic terms and compared OHS with Media Lengua and Ma'á. He states that OHS (or Stadin Slangi, 'Slang of the City', as he more vaguely says) shares more properties with Ma'á than with Media Lengua, and draws the conclusion that OHS "does not 
fit the prototype of an intertwining mixed language variety completely - - but it comes close to it, even if it probably never was an autonomous system". Wälchli's view will be further discussed in the concluding section of this paper.

Wälchli also pays attention to slang suffixes, or 'enlargements', as he calls them. Although Finnish scholars have commonly noted that slang suffixes are semantically empty and show considerable variation, their function has never been thoroughly discussed. Wälchli points out that with the slang suffixes, it has been possible to accommodate Swedish words to Finnish morphology. (See section 4.2.)

Kallio (2007) calls OHS ("early Stadin Slangi”) a lingua franca (following the notion of Paunonen) and also likens it to pidgins; the latter view is critically discussed in the conclusion. Otherwise he does not differentiate between OHS and modern slang variants, but speaks of Helsinki Slang in general. This is clearly seen when he gives "150 examples of borrowed 'basic vocabulary' items"; words of the list are from different eras. Nonetheless, it is easy to agree that OHS acquired many core vocabulary items from Swedish and other "non-Finnish" sources. Kallio compares Helsinki Slang vocabulary with Morris Swadesh's 200 basic word list; the idea was first presented by Wälchli (2005). I return to the issue in section 4.1.

Although Kallio admits that OHS had a lot in common with "other popular candidates for mixed languages" like Media Lengua and Ma'á, he states that it is "genetically" a Finnic language or dialect of Finnish. This apparent contradiction is based on his position that "genetic relatedness should always be based on grammatical rather than lexical evidence". Thus, Kallio does not only deny the status of OHS as a mixed language, but the concept of an intertwining mixed language in general. Therefore, he says that contrary to Michif and Mednyj Aleut, which are "the two best candidates for mixed languages", OHS cannot be considered a mixed language.

Apparently the most important reason for such a statement is that Kallio deprecates glottochronology and lexicostatistics, and uses OHS as a counter-example: although its core vocabulary is not Finnish, it is 'genetically' (i.e. by morpho-syntax) a Finnic language. Nonetheless, his arguments are blurred by the fact that he interweaves OHS with present slang and colloquial variants of Finnish.

\section{Contact-based features in OHS}

\subsection{Vocabulary}

At first glance, the most prominent feature of OHS is vocabulary. According to Paunonen (2006:51) "almost 80 percent" of the OHS vocabulary is Swedish. This is a considerable amount, even though he does not present any statistics or calculations supporting this number. Earlier he referred to research, which states that the proportion of Swedish words is considerably smaller, 51.2 \% (Paunonen, 1995:22).

Both numbers should be viewed with suspicion. At first, it is not evident which words qualify as OHS vocabulary; it is even questionable if the vocabulary of OHS can be distinguished from Finnish and Swedish vocabulary. Forsskåhl (2006:63) remarks that Finnish OHS speakers might use "any Swedish words they knew"; that is to say, there was no discrete OHS vocabulary. On the other hand, Wälchli (2005) points out that Swedish-based words have not displaced the Finnish ones but co-exist with them. The startling 80 percentage of Swedish words in the OHS vocabulary is acceptable only in so far as where the 'real' slang vocabulary is concerned, i.e. only the words not existing in Standard Finnish or in Finnish dialects are counted. It must be remembered that OHS had been spoken not instead of but alongside Finnish and Swedish, and the language forms can not be neatly separated from each other.

Even if there were some agreement of OHS vocabulary, it would not be simple to define the proportion of Swedish words, as many words are of unknown origin. As already mentioned, words 
are not based on Standard Swedish alone, but on various Finland Swedish dialects and inner city Swedish slang, and there are also several Russian words. Even when a word is of Finnish origin, it may be manipulated so that it is questionable if it is Finnish anymore: dullaa $(?<<$ Finn. tallaa-) and skansikse- ( $<$ Finn. kansanruokala) in example (5) are such cases. Manipulation is not restricted to Finnish words only, as example (4) with fatši $\left(<\right.$ Sw. fader) and mutši $(<$ Sw. mor, moder $)$ shows. ${ }^{7}$

In order to understand the nature of OHS vocabulary, it seems not very relevant to estimate proportions of etymological sources. More essential is that nouns, adjectives and verbs are remarkably 'Un-Finnish'. The peculiar vocabulary is partly due to the variation in source language forms, but it also serves as a linguistic marker of group identity. Apparently this is also why the words are so commonly manipulated. In this sense, OHS approaches various cant languages.

When OHS follows Finnish morpho-syntax, it is to be expected that it also uses Finnish words in grammatical functions: conjunctions, adpositions and pronouns are overwhelmingly Finnish, as is the case with most adverbs and numerals. In the examples above most Finnish words fall into these categories: there are conjunctions ( $j a$ 'and', mutta 'but', kun 'when'), pronouns ( $m \ddot{a}$ 'I', se 's/he; it', toi : to- 'that'), adverbs (nyt 'now', sit 'then'), numerals (yhde- 'one', viisi 'five'), and an auxiliary or copula olla : oli- 'to have, to be'. On the other hand, OHS adverbs are not invariably Finnish: there is a Swedish adverb tvärt 'soon' in example (5). Other Swedish adverbs in OHS are for example vek $\sim$ veg 'out, away' ( $<$ Sw. väg 'way'), vilde $\sim$ vilt 'very, a lot' ( $<$ Sw. vildt 'wildly'), liite liitte $(<\mathrm{Sw}$. lite $)$ 'a little', and slyyt $(<\mathrm{Sw}$. slut 'end, over'); skoraa 'soon' comes from Russian $(<$ skóro). Most adverbs are uninflected like in Finnish, but sometimes they may get some Finnish case endings. For example, messi- 'with, along' ( $<$ Sw. med sig 'with') and mella- $(<\mathrm{Sw}$. mellan 'between') in OHS examples (9) and (11) have Finnish illative and inessive case endings, and they are used exactly same way as Finnish adverbs muka- 'with' and väli- 'between' in Finnish examples (10) and (12).

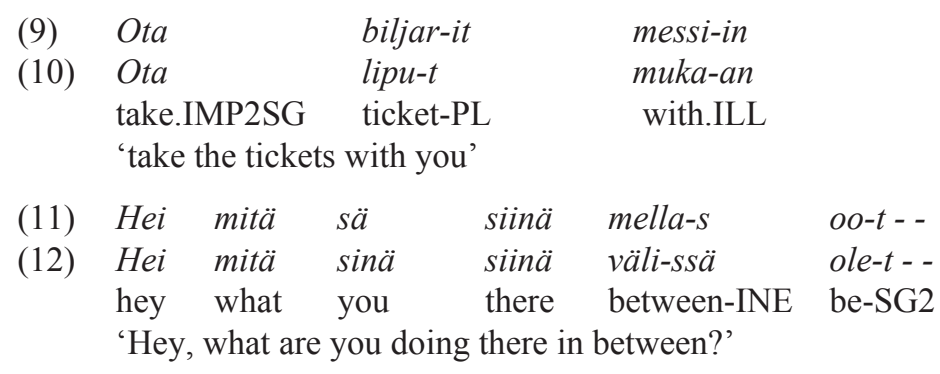

OHS numerals seem to be Finnish by origin, but Swedish numbers are commonly used as nouns, specially about notes, coins, trams or buses, and street or flat numbers, as fimtsika ' 50 pence' in example (5). In the following example, a noun femma ( $<$ Sw. femma '(number) five') and a verb budja- (< Sw. bo 'to live') are of Swedish origin. The pronouns se and tos, an adverb kai and the street name Linjoilla are Finnish.
(13) $\mathrm{Se}$ tos
Linjoi-lla,
femma-lla,
kai budja-s.
$\mathrm{He}$ there (street name)-ADE five-ADE
perhaps live-PAST.3SG

'I think he lived there at the $5^{\text {th }}$ Linja'

Since OHS should not be considered as a variant of Finnish, Swedish vocabulary is not attributable to massive borrowing from Swedish to Finnish. It is more appropriate to state that Swedish vocabulary has been embedded to dialectal Finnish matrix (Paunonen, 2006:57). This mixture has been enhanced by manipulating both Swedish and Finnish words so that they look even

\footnotetext{
${ }_{8}^{7}$ See also the list of core vocabulary derived from Swedish- below in example (14).

${ }^{8}$ In Helsinki, there are five streets called Linja (Sw. Linjen) 'Line' and they are numbered from $1^{\text {st }}$ to $5^{\text {th }}$.
} 
extravagantly Un-Finnish.

It is generally expected that core vocabulary or 'basic vocabulary' will be maintained even in intensive borrowing situations (e.g. Thomason \& Kaufman, 1988:48). Thus, if OHS were a variant of Finnish, there should be more Finnish words in its core vocabulary. Apparently this is not the case. Both Wälchli (2005) and Kallio (2007) have presented OHS equivalents to items of the 207 words Swadesh list, although they have also included modern slang words. Wälchli gives almost 60 words of Swedish origin. Kallio has 150 examples in his list of "borrowed 'basic vocabulary' items", but there are some words outside the Swadesh list. On the other hand, it should be remembered that about 30 words on the Swadesh list are pronouns, question words, numerals and conjunctions. Therefore, it is feasible that about $80 \%$ of verbs, adjectives and nouns in Swadesh list have Un-Finnish (mostly Swedish) equivalents in OHS. The following list is not exhaustive, but it illustrates how commonly OHS vocabulary is based on Swedish, and how widely there is phonological and morphological variation.

\begin{tabular}{|c|c|c|c|}
\hline English & OHS & Swedish & \\
\hline big & buli $\sim$ puli & bulen & (Kallio, 2007) \\
\hline long & longa $\sim$ lonka & lång & \\
\hline thick & tšokkis $\sim$ tsokkis & tjock & \\
\hline small & snadi & (s)nadd & (Kallio, 2007) \\
\hline short & spädä & späd & 'little, fine' \\
\hline woman & bööna & böna 'bean' & \\
\hline $\begin{array}{l}\operatorname{man} \\
\text { (male) }\end{array}$ & bisi $\sim$ bisse $\sim$ bišše & (Sibbo dial.) bisse & \\
\hline child & kloddi & klodd & (Sibbo dial.) \\
\hline mother & mutsi $\sim$ mutši $\sim$ mude & mor, moder & \\
\hline father & fatsi $\sim$ fatši $\sim$ fade $\sim$ faija & far, fader, faja & (Kallio, 2007) \\
\hline fish & fisu $\sim$ fišu & fisk & \\
\hline bird & fogeli $\sim$ fokeli & fågel & \\
\hline $\operatorname{dog}$ & hunde $\sim$ hundi & hund & \\
\hline louse & flatsku $\sim$ flatari $\sim$ fladari & flatlus & 'crab louse' \\
\hline worm & masi $\sim$ maski & mask & \\
\hline tree & vedu $\sim$ fedu & vedd & \\
\hline forest & skuge $\sim$ skuke $\sim$ skuija $\sim$ skog & skutši $\sim$ kutši $\sim$ skutta & \\
\hline stick & tšeba $\sim$ tšepa & käpp & \\
\hline flower & blomma $\sim$ blomsteri $\sim$ blumsteri & blomma, blomster & \\
\hline grass & gresa $\sim$ grese $\sim$ gresi & gräs & \\
\hline meat & šöte $\sim$ sköte $\sim$ tšöte $\sim$ tšöde & kött & \\
\hline blood & blode $\sim$ bluda $\sim$ blude $\sim$ bludis & blud & \\
\hline fat & smörja & smörja & \\
\hline egg & eggi $\sim$ egi $\sim$ egu & ägg & \\
\hline head & $\begin{array}{l}\text { knubbi } \sim \text { knuppi } \sim \text { knube } \sim \text { knubu } \sim \\
\text { knubura }\end{array}$ & knopp 'bud, knob' & \\
\hline ear & ööra & öra & \\
\hline eye & ööga $\sim$ ööka $\sim$ öögä $\sim$ öögoni & öga, (plural) ögon & \\
\hline nose & nesa $\sim$ knesa & näsa & \\
\hline mouth & munnari $\sim$ munni $\sim$ munnu & munn & \\
\hline foot & futi $\sim$ futu & fot & \\
\hline hand & handu $\sim$ hande $\sim$ handi & hand & \\
\hline belly & maga $\sim$ maka & mage & \\
\hline to drink & dokaa & (dial.) dåka & \\
\hline to eat & $\begin{array}{l}\text { skruutaa } \sim \text { skruudaa } \sim \text { sgruutaa } \sim \\
\text { sgruudaa } \sim \text { gruutaa }\end{array}$ & skrota & \\
\hline to bite & tuggaa & tugga 'bite, chew' & \\
\hline
\end{tabular}




\begin{tabular}{|c|c|c|c|}
\hline to spit & spottaa & spotta & \\
\hline to vomit & spyttaa, pyttaa & spy & \\
\hline to blow & blosaa $\sim$ bloosaa & blåsa & \\
\hline to laugh & griinaa $\sim$ kriinaa $\sim$ skriinaa & grina & \\
\hline to know & tšennaa $\sim$ tsennaa & känna & \\
\hline to think & $\begin{array}{l}\text { fundeeraa } \sim \text { funtsaa } \sim \text { funtšaa } \sim \\
\text { funtsia } \sim \text { funtšia }\end{array}$ & fundera, (slg.) funtja & \\
\hline to smell & $\begin{array}{l}\text { döfaa } \sim \text { döffaa } \sim \text { döfää } \sim \text { dövaa } \sim \\
\text { dövää } \sim \text { döftaa } \sim \text { döftää }\end{array}$ & dofta & \\
\hline to fear & skagaa $\sim$ skakaa $\sim$ sgagaa & skaka 'shake' & \\
\hline to sleep & koisaa $\sim$ goisaa & kojsa & $\begin{array}{l}\text { (Kallio, 2007), } \\
\text { cf. koj 'a bed' }\end{array}$ \\
\hline to live & levaa leevaa & leva & \\
\hline to die & kolaa $\sim$ golaa $\sim$ skolaa & (slg.) kola & \\
\hline to kill & mördaa & mörda & \\
\hline to cut & šäraa & skära & \\
\hline to stab & stikkaa & sticka 'sting' & \\
\hline to scratch & skrabaa $\sim$ skrapaa $\sim$ krapaa & skrapa & \\
\hline to dig & grevaa $\sim$ krevaa $\sim$ skrevaa & gräva & \\
\hline to swim & simmaa $\sim$ tsimmaa & simma & \\
\hline to fly & flygaa $\sim$ flykaa & flyga & \\
\hline to sit & sittaa $\sim$ tsittaa & sitta & \\
\hline to stand & stondaa & stå(nda) & \\
\hline to wash & tvettaa & tvätta & \\
\hline to count & räknää räknaa & räkna & \\
\hline to say & sprookaa $\sim$ sproogaa & språka 'speak, talk' & \\
\hline to sing & šungaa tšungaa & sjunga & \\
\hline to freeze & frysaa & frysa & \\
\hline sun & $\begin{array}{l}\text { suulis } \sim \text { suullis } \sim \text { suulinki } \sim \\
\text { suulberi } \sim \text { suulperi }\end{array}$ & sol & \\
\hline water & vatu $\sim$ vadu & vatten & \\
\hline to rain & rengaa, regnaa, rengnaa & regna & \\
\hline sea & sköne, sgöne & sjö & \\
\hline salt & saltti & salt & \\
\hline stone & $\begin{array}{l}\text { stena } \sim \text { stenari } \sim \text { stenu } \sim \text { stemu } \sim \\
\text { steba } \sim \text { stebari } \sim \text { stepari }\end{array}$ & sten & \\
\hline wind & blosis $\sim$ bloosis & blåst & \\
\hline snow & snöge $\sim$ snöke & snö & \\
\hline cold & kalsa $\sim$ galsa & kalt & \\
\hline
\end{tabular}

There also some core vocabulary words derived from Russian, like voda 'water' (< vodá), kaveeraa kaveraa 'to say' (< govorit' 'to speak'), snaijaa 'to know' $(<$ znaj-), and nietu 'not' $(<$ nétu). Groussi groušši $\sim$ grousi kroussi krousi 'big' comes from German groß.

\subsection{Slang suffixes}

It has been frequently mentioned above that in OHS, it is quite common to manipulate words with specific enlargements called 'slang suffixes', of which the most common are -ari, $-i s$, and - tš $i$ $\sim-t s i$. There are several examples in the core vocabulary list above (14): the suffix -ari is in flatari $\sim$ fladari 'louse' ( $<$ Sw. flatlus), munnari 'mouth' $(<$ Sw. munn) and stenari $\sim$ stebari $\sim$ stepari 'stone' ( $<$ Sw. sten); the suffix $-i$ is išokkis $\sim$ tsokkis 'thick' $(<$ Sw. tjock), bluudis 'blood' $(<$ Sw. blod), suulis $\sim$ suullis 'sun' ( $<$ Sw. sol), and blosis $\sim$ bloosis 'wind' ( $<$ Sw. blåst); the suffix $-t s ̌ i$ is in mutši, fatši and skutši 'forest' ( $<$ Sw. skog). The slang suffixes have no semantic content and they do not express any grammatical relations. Thus, the term 'suffix' is inadequate here, as it refers to 
morphemes with a grammatical function (e.g. case endings, plural markers). The term is used here for traditional reasons, as in Finnish literature a parallel term slangisuffiksi is widely used; Wälchli (2005) calls slang suffixes 'enlargements'.

From the start, the slang suffixes have probably been used to accommodate Swedish words into the Finnish grammatical system (the point first discussed by Wälchli 2005). Finnish words typically consist of two syllables and end with a vowel. There are only a few mono-syllabic words ending with a consonant - on the other hand, the latter are common in Swedish. For example, it is not possible to use the Swedish words munn 'mouth', sten 'stone', sol 'sun', and blod 'blood' in Finnish as such, because Finnish case endings typically begin with a consonant, as - $n$ (genitive), $s s a /-s s \ddot{a}$ (inessive) - ksi (translative) etc. The tendency that stems have to end in a vowel is clearly seen in example (3), where Swedish the newspaper name Svenska Pressen is in the partitive case: Svenska Presseni-ä.

A typical strategy in Finnish, as well as in OHS, is just to add a spare vowel after a stem, as the vowel $-a / \ddot{a}$ in longa $<$ lång, spädä $<$ späd, and tšepa $<k \ddot{a} p p$; the vowel $-i$ in snadi $<(s)$ nadd, maski $<$ mask, and munni < munn; and the vowel $-u$ in fisu < fisk, vedu $<$ vedd, and egu $<$ ägg. As the list above shows, the vowel $-e$ is also common, as in blude, hunde and skuuge, but it apparently has its origin in Swedish definite suffixes: blod-et 'the blood', hund-en 'the dog', skog-en 'the forest' etc. Furthermore, the $-e$ is also used as a slang suffix with an 'unetymological' consonant, as in sköne (< Sw. sjö) and snöge $\sim$ snöke $(<\mathrm{Sw}$. snö). Thus, by its origin and function the $-e$ is somewhat more complex than other spare vowels.

Nevertheless, OHS does not only use spare vowels in order to accommodate Swedish words, but slang suffixes, as in munnari $(<\mathrm{Sw}$. munn + slang suffix -ari), stenari $(<\mathrm{Sw}$. sten + -ari), bludis $(<$ Sw. blod $+i s)$, suulis $(<\mathrm{Sw}$. sol $+i s)$, and dörtši 'door' (Sw. dörr $+t \check{s} i)$. In these cases, slang suffixes have a clear morphological function, parallel to spare vowels. But they are not just added after an original word, for in many cases there is clipping-with-enlargement: examples are flat-ari 'louse' (flat- < Sw. flatlus), fön-ari 'window' (fön- < Sw. fönster), gos-ari 'janitor' (gos- < Sw. gårdskarl); studis 'Students' house' (stud-<studentshuset), labbis 'laboratory', krabb-is 'hangover' (krabb- << lat. crapula); mu-tši (mu- < mor, moder), sku-tši (sku- < skog), and frö-tši 'schoolmistress' (frö-<fröken 'miss').

Thus, one function of slang suffixes is apparently "to give the new words a more uniform phonotactic structure" (Wälchli, 2005). For this reason, slang suffixes are also used with Finnish words, which hence become uniform with Swedish words. For simm-arit 'swimming trunks' and samm-arit 'velvet trousers', first comes from Swedish $(<$ simbyxor $)$ and second from Finnish $(<$ samettihousut). Fut-is 'football' ( $<$ fotboll) is Swedish, pes-is 'baseball' ( $<$ pesäpallo) is Finnish. There are two OHS words for 'cliff, rock': bär-tši $\sim$ pär-tšs $(<\mathrm{Sw}$. berg) and kal-tši $\sim$ gal-tši $(<$ Finn. kallio).

Interestingly, some slang suffixes themselves are of foreign origin. The slang suffix -ari is originally a Swedish agent suffix - are used in many Swedish loan words in Finnish (Finn. tuomari $<$ Sw. domare 'referee, judge', muurari < murare 'bricklayer', colloquial vekkari < väckare 'alarm clock'). The slang suffix -is has apparently come into OHS with Swedish slang words: the early Swedish inner city slang had several words ending with $-i s$, as rudis 'rudimentary, stupid' (apparently from Latin), maskis ( $<\mathrm{Sw}$. maskerad) 'masquerade', kondis ( $<\mathrm{Sw}$. konditori) 'bakery, café', and gosis (< Sw. gårdskarl) 'school caretaker' (Forsskåhl, 2006:59). A slang suffix -de has its origin in the definite form of Swedish words ending with $d$ (as in words blude $<$ Sw. blod-et 'the blood', and hunde < Sw. hund-en 'the dog'), but hereafter it is also used in Finnish words, as jä-de $(<$ Finn. jäätelö) and pi-de (< Finn. piha) 'yard'.

The Finnish language is rich in derivative suffixes, and semantically free suffix alternation occurs in many Finnic languages. In this respect, the slang suffix system would seem to be part of 
Finnish morpho-syntax in OHS (Kallio, 2007). Yet it should be noted that the slang suffixes do not incorporate Swedish OHS words into the Finnish system, but rather vice versa: OHS words originating from Finnish like skansis $(<$ kansanruokala) and jäde $(<$ jäätelö) are alienated with slang suffixes, and they even take on a sort of pseudo-Swedish appearance. Thus, slang suffixes have the same function as hypercorrect voiced stops and word-initial consonant clusters discussed in the next subsection (4.3). Moreover, several slang suffixes are of Swedish origin, and a mechanism with clipping-and-enlargement is exactly the same as in Swedish slang words with -is (see rudis, maskis, kondis above). Thus, the slang suffix system seems to be a Swedish contribution, although it also includes OHS innovations and fulfils some needs of Finnish morpho-syntax.

\subsection{Phonology and phonotactics}

Although OHS follows Finnish grammar, it has several phonological and phonotactical properties, which are adistinct from Finnish dialects. The voiced stops $b, d$, and $g$, voiceless palatoalveoral sibilant $\check{s}$ and affricate $t \check{s}$, which do not occur in all Finnish dialects, are common in OHS vocabulary. They may occur as equivalents of Swedish phonemes, as the $b$ in blomma $(<$ blomma $)$ 'flower', the $d$ in döftaa (< dofta) 'smell', the $g$ in gresa (< gräs) 'grass', the š in šäraa (< skära) 'to cut', and $t \check{s}$ in $t \check{s}$ epa (<käpp [tšep]) 'stick'. Moreover, the voiced stops are used hypercorrectly when there is a voiceless stop in Swedish word: knubbi 'head' $(<\mathrm{Sw}$. knopp), vadu 'water' ( $<\mathrm{Sw}$. vatten), and galsa 'cold' ( $<$ Sw. kalt). Similarly, the voiceless stops of Finnish words may have been replaced with voiced stops: burari 'porridge' $(<$ Finn. puuro), dallaa 'walk' ( $<$ Finn. tallaa'trample'), galtsi 'cliff' (< Finn. kallio). The affricate $t \grave{s}$ may sometimes appear instead of $k$, as in tšufe (cf. Sw. kaffe) 'coffee' and tšiegura 'ring-shaped sausage' from Finnish kiekura 'ring'. These hypercorrect forms show that the phonemes which are uncommon in Finnish have a special prestige, and together with slang suffixes they have become markers of OHS words.

The same goes for the unvoiced fricative $f$ and word-initial consonant clusters; even though they are known in Western Finnish dialects to some extent, they are significantly more frequent in OHS. There may be regular equivalents in Swedish words, as fisu 'fish' (< fisk), spädä (< späd) 'short', skuge (< skog) 'forest', gresa 'grass' (< gräs), frysaa 'freeze' (< frysa), flygaa 'fly' (< flyga), tvettaa 'wash' ( $<$ tvätta) etc. They also occur commonly in hypercorrect Swedish forms, as fedu 'tree' (< Sw. ved), knesa 'nose' (< näsa), tsittaa 'sit' $(<$ sitta), and sköne 'sea' $(<$ sjö [šö:]), and Finnish forms, as klide 'cellar' (< Finn. liiteri 'shed') skansis 'people's canteen' (< Finn. kans-), and travaa 'walk, run' (< Finn. ravaa- 'trot'). Sometimes a third consonant is added to an original Swedish cluster of two consonants: skriinaa 'laugh' (< grina) and skrevaa 'dig' (< gräva).

OHS also commonly violates phonotactical restrictions occurring in Finnish like vowel harmony. This phonological restriction makes it impossible to realize back vowels $(a, o, u)$ and front vowels $(\ddot{a}, \ddot{o}, y)$ in the same word (e and $i$ are neutral in this sense, and they can occur with both front and back vowels). The Swedish language does not know the restriction, which is also seen in the OHS words such as ööga 'eye' $(<\mathrm{Sw}$. ööga), räknaa 'to count' $(<\mathrm{Sw}$. räkna) and spyttaa 'vomit' $(<\mathrm{Sw}$. spy). Sometimes even the Finnish words are manipulated so that they violate vowel harmony: in addition to järkkää 'organize' (< Finn. järjestää) there is a variant järkkaa. Nonetheless, vowel harmony operates in the selection of the suffixal vowel (Kallio, 2007): for järkkää, the participle is järkä/nny, passive järkä/tään etc, but for järkkaa parallel forms would be järka/nnu, järka/taan etc.

The phonological and phonotactical properties mentioned above have evidently come to OHS with Swedish words, and they have brought the OHS consonant system rather close to (Finland) Swedish. In contrast, the OHS vowel system is Finnish and there are no parallels to Swedish central vowels. The quantity system of consonants and vowels is also identical in OHS and Finnish. 


\subsection{Morphology}

The morpho-syntax of OHS seems to be rather genuine Finnish. All the words are inflected following the rules of (dialectal) Finnish. There are still some peculiarities, which have no parallel in Finnish dialects, so they are apparently innovations in OHS. But it is difficult to determine if the peculiarities are due to contact-induced changes or internal development.

As stated above (section 4.2), the development of slang suffixes was probably initially triggered by the Swedish influence, but they also comply with the rules of Finnish morpho-syntax. At first, when a Swedish original word ends with a consonant, it must be manipulated so that it ends with a vowel; otherwise it could not be inflected by Finnish grammar. The slang suffixes make Finnish inflection possible, even though spare vowels $(-a,-i,-u)$ have the same function. Secondly, in some cases a word can be accommodated to simple inflection categories, when a slang suffix is added.

For example, following the consonant gradation rules of Finnish, the quantity of an unvoiced stop has a weak $(k, p, t)$ and strong $(k k, p p, t t)$ grade when a word is inflected (and the stop is a last consonant in a stem). There is a strong tendency that borrowed words, which originally ended with a stop, are accommodated to this system. Thus, a Swedish noun kort 'card' has been borrowed into Finnish as kortti 'a card'. The quantity of $t \sim t t$ alters in the following way (the list is not exhaustive, since there are 14 cases in Finnish):

\begin{tabular}{|c|c|c|c|c|c|}
\hline $\begin{array}{l}\text { kortti: } \\
\text { SG.NOM }\end{array}$ & $\begin{array}{l}\text { kortti-a: } \\
\text { SG.PART }\end{array}$ & $\begin{array}{l}\text { kortti-in } \\
\text { SG.ILL }\end{array}$ & $\begin{array}{l}\text { kortti-en } \\
\text { PL.GEN }\end{array}$ & $\begin{array}{l}\text { kortte-j-a: } \\
\text { PL-PART }\end{array}$ & $\begin{array}{l}\text { kortte-i-hin } \\
\text { PL-ILL }\end{array}$ \\
\hline $\begin{array}{l}\text { korti-n : } \\
\text { SG.GEN }\end{array}$ & $\begin{array}{l}\text { korti-ssa: } \\
\text { SG.INE }\end{array}$ & $\begin{array}{l}\text { korti-lla: } \\
\text { SG.ADE }\end{array}$ & $\begin{array}{l}\text { korti-t: } \\
\text { PL.NOM }\end{array}$ & $\begin{array}{l}\text { kort-ei-ssa: } \\
\text { PL-INE }\end{array}$ & $\begin{array}{l}\text { korte-i-lla } \\
\text { PL-ADE }\end{array}$ \\
\hline
\end{tabular}

Respectively, if OHS followed this Finnish system, there should be, for instance, *kaltti 'cold' from Swedish kalt, and *tšokki 'thick' from Swedish tjock. These hypothetical words would have consonant gradation, as kortti in example (15). But instead of them, OHS has kalsa and ťsokkis. These innovations are inflected without consonant gradation: SG.GEN kalsa- $n$, tšokkikse- $n$, SG.PART kalsa-a, ť̌okkis-ta, SG.ILL kalsa-an, ťsokkikse-en and so on. This may be one reason why slang suffixes are used, but it is not a comprehensive explanation as there are many OHS words conjugating similarly as kortti, for example knuppi 'head' $(<\mathrm{Sw}$. knopp) and saltti $(<\mathrm{Sw}$. salt). The tendency of avoiding consonant gradation is more apparently seen with verbs, as will be discussed below.

Another complicated process of stem variation in Finnish grammar is that the stem-final vowels commonly alter in the plural; a most common alteration is $i \sim e$. This is seen in example (15), where a singular stem is kortti- $\sim$ korti, but the plural stem is korttei- $\sim$ kortei-. It is probably for this reason that $u$ is a common spare vowel in many slang words, for it does not alter in the plural. This is shown by the following example, which illustrates the inflection of common handu and significantly less usual handi, both originating from the Swedish hand. The stem handu- remains the same, whilst handi- is altering with hande-.

$\begin{array}{lllllll}\text { handu } & \text { handu- } n & \text { handu-j-en } & \text { handu- } a & \text { handu-j-a } & \text { handu-ssa } & \text { handu-i-ssa } \\ \text { SG.NOM } & \text { SG.GEN } & \text { PL-GEN } & \text { SG.PART } & \text { PL-PART } & \text { SG.INE } & \text { PL-INE } \\ \text { handi } & \text { handi- } n & \text { handi-en } & \text { handi- } a & \text { hande-j-a } & \text { handi-ssa } & \text { hande-i-ssa } \\ \text { SG.NOM } & \text { SG.GEN } & \text { PL.GEN } & \text { SG.PART } & \text { PL-PART } & \text { SG.INE } & \text { PL-INE }\end{array}$

In conclusion, Swedish nouns in the OHS do not violate the Finnish inflection system, although they, to some extent, avoid complicated phonological alterations. It is a common tendency in many languages that new words favour simple inflection categories; thus, this it is not necessarily a 
contact-induced feature in OHS. It must still be remembered that in Swedish, the stems alter very little.

With verbs, the situation is somehow more peculiar. In OHS the majority of verbs are declined in a way which is unheard of in Standard Finnish and most Finnish dialects, even though its roots are in Finnish dialects spoken near Helsinki (Sorsakivi, 1982:381).

This peculiar OHS conjugation is apparently a simplified form from a Finnish conjugation called fourth in many text books, and it may also be interpreted as a hybrid of first and fourth conjugation. The first and fourth conjugations are illustrated in the following table with verbs ottaa 'to take' and mittaa- 'to measure'.

$\begin{array}{lll}\text { INF } & \begin{array}{l}\text { First conjugation } \\ \text { otta- } a \text { 'to take' }\end{array} & \begin{array}{l}\text { Fourth conjugation } \\ \text { mitat- } a \text { 'to measure' } \\ \text { mittaa- } n\end{array} \\ \text { PRES.1.SG } & \text { ota- } n & \text { mittaa } \\ \text { PRES.3.SG } & \text { otta- } a & \text { mitta-sin } \\ \text { PAST.1.SG } & \text { ot-in } & \text { mitta-si } \\ \text { PAST.3.SG } & \text { otti } & \text { mitat-kaa } \\ \text { IMP.2.PL } & \text { otta-kaa } & \text { mitan- } \text { nut } \\ \text { PARTCP } & \text { otta- } \text { nut } & \text { mitat-aan }\end{array}$

Swedish word stems would most naturally fall into either of these conjugations, as these are the only Finnish conjugation categories for verb stems ending with $-a$, which is the most common last vowel in Swedish verbs. It is easily noticed from the table that a verb stem alters more in the first than in the fourth conjugation: in the first, there is the alteration otta- $\sim$ ota- $\sim$ otti- $\sim$ oti- $\sim$ ote-; in the fourth, there is the alteration mitta(a)- mitat-. Furthermore, it should be remembered that alteration in the fourth conjugation is only due to consonant gradation; if there is no unvoiced stop in a stem, it alters only minimally, as maala $(a)-\sim$ maalat- 'to paint'. 9 For this reason, the overwhelming majority of recently borrowed verbs have fallen into the fourth category in Standard Finnish.

In OHS, almost all Swedish verbs follow the fourth conjugation, but there are some differences in the forms where a consonant stem (which triggers consonant gradation) should be used. The forms are the infinitive (18), the imperative for $2^{\text {nd }}$ person plural (19), the active participle (20) and passive past tense (21).

$\begin{array}{lll}\text { täyty } & \text { dilkkaa } & \text { lehde-t } \\ \text { have.to.PAST } & \text { deliver.INF } & \text { newspaper-PL } \\ \text { '[Before the school, ] the newspapers should be delivered' }\end{array}$

$\begin{array}{lll}\text { tvetta-kaa } & \text { se- } n & \text { klabbi-t } \\ \text { wash-IMP.2PL } & \text { he-GEN } & \text { foot-PL }\end{array}$

'wash his feet'

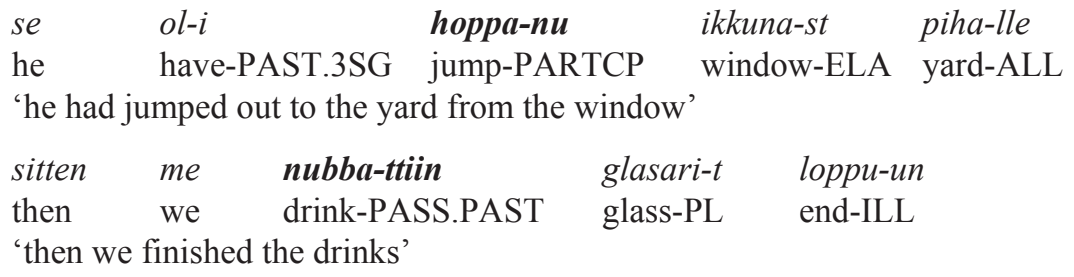

The forms dilkkaa, tvettakaa, hoppanu and nubbattiin should be *dilkata, *tvetatkaa, *hopannut

\footnotetext{
${ }^{9}$ Standard Finnish loan from Swedish måla.
} 
and $*_{n u b a t t i i n}$ according to Finnish grammar. ${ }^{10}$ Thus, there is the apparent tendency for avoiding consonant gradation. As a result of the previous examples, the peculiar OHS conjugation may be postulated (unequal forms are in boldface):

\begin{tabular}{|c|c|c|}
\hline INF & $\begin{array}{l}\text { Fourth conjugation } \\
\text { mitat-a 'to measure' }\end{array}$ & $\begin{array}{l}\text { OHS conjugation } \\
\text { tvettaa 'to wash' }(<\mathrm{Sw} \text {. } \\
\text { tvätta })\end{array}$ \\
\hline PRES.1.SG & mittaa-n & tvettaa- $n$ \\
\hline PRES.3.SG & mittaa & tvettaa \\
\hline PAST.1.SG & mitta-sin & tvetta-sin \\
\hline PAST.3.SG & mitta-si & tvetta-si \\
\hline IMP.2.PL & mitat-kaa & tvetta-kaa \\
\hline PARTCP & mitan-nut & tvetta-nu \\
\hline PASS.PRES & mitat-aan & tvetta-taan \\
\hline
\end{tabular}

In the OHS conjugation there is no consonant stem (and therefore no consonant gradation), which is clearly seen in the infinitive having a vowel stem in OHS, e.g. tvettaa 'to wash' and dilkkaa 'to deliver' instead of *tvetata and *dilkata. There is only one stem (a vowel stem) in the whole paradigm, which considerably simplifies the conjugation.

Thus, the same basic tendency of avoiding alterations in a stem affects both nouns and verbs. With nouns, stems are manipulated by enlargements; with verbs, the other of the two original stems is omitted. Both processes are also applied to Finnish words: nouns of Finnish origin may have enlargements, and Finnish verbs of the fourth conjugation may also lose their consonant stem. This is common in the infinitive, as in (23), which has infinitive kyttää 'watch' (cf. dilkkaa in 18) instead of Standard Finnish kytätä. Example (24) shows a participle form leikka-nu (cf. hoppanu in 20) instead of Standard Finnish leikan-nut.

$\begin{array}{lllll}\text { kaike-st kiva-mpa ol-i } & \text { kyttää } & \text { kirjailija } & \text { Ry } \\ \text { all-ELA nice-COMP } & \text { be-PAST.3SG } & \text { watch.INF } & \text { writer } & \text { (name } \\ \text { 'It was nicest to watch writer Runeberg's home' } & & \\ \text { se } \quad \text { o-li- } & \text { leikka-nu} & \text { knivu-lla } & \text { sorme-en } \\ \text { he be-PAST.3SG slit-PARTCP } & \text { knife-ADE } & \text { finger-ILL } \\ \text { 'He had slit his finger with a knife' } & & \end{array}$

\subsection{Syntax}

Although data concerning syntax in OHS is rather limited, it is evident that there have been some anomalies which were not documented for contemporary Finnish dialects. For example, the object's case selection has not followed the rules of Standard Finnish grammar (Paunonen, 2000:25). Finnish object has three cases: nominative, genitive and partitive. In following example (25), the object nime- $t$ 'names' is in nominative, although in Standard Finnish it should be in partitive case (nimi-ä). In the next example (26), the object kauhee nippu 'huge pile' is in nominative, but in Standard Finnish it should be in the genitive: kauhee- $n$ nipu- $n$. Otherwise these examples are genuine (dialectal) Finnish, by both grammar and vocabulary.

... mä en muista niiden nime-t

... I no remember they.GEN name-PL

'I do not remember their names'

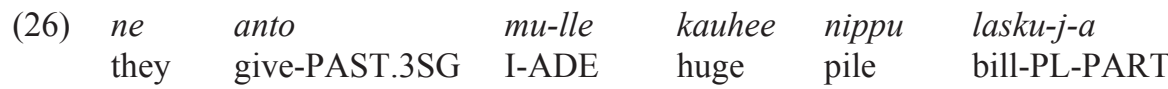

${ }^{10}$ Consonant gradation does although not definitely work with voiced stops. 
'they gave me a huge pile of bills'

In the following two examples, the objects semmose-n käytety-n futari- $n$ 'such a used football' and borsta-n, planki-n ja sameti-n 'brush, shoe polish and velvet' are in genitive case, although in Standard Finnish they were in nominative. In this examples, there are also several OHS words, as slumppaa 'to buy' (etymology unknown), futari $(<\mathrm{Sw}$. fotboll) 'football', borsta ( $<\mathrm{Sw}$. borste) 'brush', plankki $(<\mathrm{Sw}$. blank) 'shoe polish' and bungaa $(<\mathrm{Sw}$. punga $)$ 'to pay'.

$\begin{array}{llllll}\text { me saa-tiin } & \text { joskus } & \text { slumppaa } & \text { semmose- } n & \text { käytety-n } & \text { futari- } n \\ \text { we get-PASS.PAST } & \text { sometimes } & \text { buy } & \text { such-GEN } & \text { used-GEN } & \text { football-GEN }\end{array}$

'sometimes we might to buy such a used football'

$\begin{array}{llllll}\text { borsta- } n, \quad \text { planki- } n & j a & \text { sameti-n } n & \text { täyty- } i & \text { bungaa } & \text { itse } \\ \text { brush-GEN shoe.polish-GEN } & \text { and } & \text { velvet-GEN } & \text { must-PAST.3SG pay.INF } & \text { self } \\ \text { 'You had to pay brush, shoe polish and velvet yourself [when you worked as a shoe-polisher]' }\end{array}$

Rules regulating the object's case selection in Standard Finnish are rather complex and partly artificial, and therefore respective examples could be occasionally found in any variant of spoken Finnish. However, in OHS, these exceptions have evidently been extraordinary common. This kind of variation in the object's case is traditionally interpreted as being an error, and it is commonly noticed in contemporary sources as an evidence of 'impure' Finnish in Helsinki. As it is typical for non-native Finnish speakers, consequently it is quite natural to assume Swedish influence here. On the basis of the scarce material it is difficult to say whether there has been some simplified scheme behind these 'errors'. In the examples given above case selection seems to alter randomly. ${ }^{11}$

A somewhat more radical feature almost surfaced in questioning sentences: the erosion of personal congruence between a predicate and a subject. In Standard Finnish, questions are made with a special questioning particle $-k o$ which is located after a personal ending:

\begin{tabular}{|c|c|}
\hline buy.PAST.1SG.QPRT & osti-n-ko (minä) \\
\hline buy.PAST.2SG.QPRT & osti-t-ko (sinä) \\
\hline buy.PAST.3SG.QPRT & osti-ko (hän) \\
\hline buy.PAST.1PL.QPRT & osti-mme-ko (me) \\
\hline buy.PAST.2PL.QPRT & osti-tte-ko (te) \\
\hline buy.PAST.3PL.QPRT & osti-vat-ko (he) \\
\hline
\end{tabular}

In OHS, a questioning particle is reduced to $-k(s)$ and the personal pronoun follows immediately a verb; for instance tsennasiks sä 'did you know' (example 30). Parallel form in Standard Finnish were *tsennasi-t-ko.

$\begin{array}{llll}\text { tsenna-si-ks } k \ddot{a} & \text { to- } n & \text { karju- } n \\ \text { know-PAST-QPRT } & \text { you } & \text { that-GEN } & \text { man-GEN } \\ \text { 'did you know that man?' } & & \end{array}$

The questioning particle $-k(s)$ occurs also in Finnish dialects, especially in Southern and Western Finland, hence it is not OHS innovation. It is also common in western dialects, that an ending for $2^{\text {nd }}$ person singular has omitted before the questioning particle; this is supposed to be due to assimilation $t k>k k$ : e.g. ostitko sä $>$ ostikko sä $>$ ostik sä (Forsberg 1994, 60). Furthermore, in OHS (and most Finnish dialects) there is no difference between the $3^{\text {rd }}$ person singular and plural, so the ending for $3^{\text {rd }}$ person plural -vat (see table 29) is not used: the questionings are of type osti-ks se (Standard Finnish osti-ko) 'did s/he buy' and osti-ks ne (Standard Finnish osti-vat-ko) 'did they buy'. Also the form for $1^{\text {st }}$ person singular is very close, for the word final $n$ is easily reduced: ostinks mä > ostiks mä.

\footnotetext{
${ }^{11}$ More examples are found in Paunonen (2000:25.
} 
So far omission of personal endings may be explained on grounds of Finnish dialects and phonological development. But in the following example, OHS has taken one step forward:
osti-ks te buy-QPRT you (PL)
Röba-n kundi-t
kledju-t sie-lt
jutšku-i-st?
'Did you buy, you Röba [a slang name for Punavuori (Sw. Rödberg), a city part] boys, your clothes from those Jews?'

The form osti-ks te (instead of osti-tte-ks te), which has no ending for $2^{\text {nd }}$ person plural, cannot be explained with phonology, but has undergone a process of reanalysis. Parallel forms are not known in any Finnish dialect. Thus, the system of questioning forms in OHS may be postulated as follows:

(32) buy.PAST.1SG.QPRT osti-ks mä

buy.PAST.2SG.QPRT osti-ks sä

buy.PAST.3SG.QPRT osti-ks se

buy.PAST.1PL.QPRT ostettii-ks me

buy.PAST.2PL.QPRT osti-ks te

buy.PAST.3PL.QPRT osti-ks ne

Only the $1^{\text {st }}$ person plural form ostettii-ks me 'did we buy' differs from the others, and even it does not have personal ending, but passive suffix, as OHS uses passive forms in $1^{\text {st }}$ person plural (this is common in Finnish dialects). All other personal endings have been lost. This is not necessarily contact-induced, but the idea that a person can only be expressed with a pronoun is most natural for a Swedish-speaker, because Swedish verbs have no personal endings.

\section{Conclusion}

It has probably become apparent that I considered OHS to be a distinct code, mixing Finnish morpho-syntax and Swedish vocabulary. Its sources are in contemporary Finnish and Swedish dialects, Swedish inner city slang and, to some extent, Russian, but it also has innovations which could not be traced to these source languages. Whether this mixed code is a register of Finnish or a language symbiotic with Finnish, is difficult to determine. If OHS is called a register of Finnish, it is understood in the first place as lexical phenomenon, a collection of peculiar words which follow Finnish grammar and are used in parallel with Finnish words, and therefore Swedish slang is separate from OHS. On the other hand, the definition of OHS as a language brings out its original function as an intermediate code between Swedish and Finnish speakers, stresses its innovations, and leaves open a possibility that it has been spoken with two grammars: either Finnish or Swedish (see examples 7 and 8).

As it is mentioned in section 3, Paunonen seems to consider OHS as language (see Paunonen, 2000:16; 2006:51, 57), whilst Wälchli (2005) and especially Kallio (2007) tend to support the idea of OHS as a variant of Finnish. Pertinent arguments could be, and have been, presented for both opinions, whereas I find it difficult to uphold the contention that OHS should be considered as a pidgin. Kallio (2007) advocates the latter view, arguing that OHS has been used in communication between two groups speaking different languages, and it had limited vocabulary and simplified Finnish grammar. Still, this position ignores the evidence that OHS was used symbiotically with Finnish or Swedish, many speakers were bilingual, and there is no established ground on which the amount of OHS words could even be estimated; furthermore, there are no documents of radically simplified Finnish grammar. More noteworthy is Kallio's point that OHS apparently had no native speakers, at least monolingual, but this fact still does not mean that OHS were a pidgin.

The most apparent contact-induced features of OHS can be summarized as follows:

Vocabulary is to a considerable extent based on Swedish, although there are also both Finnish words and a few Russian words. The proportion of words from Latin, German, English and other 
languages is marginal. A relatively large part of the vocabulary is of unknown origin. OHS lexical items are typically manipulated with slang suffixes, hypercorrect voiced stops and word-initial consonant clusters, in order to alienate the words from their origins and to give them a uniform phonotactical structure: vinkkari 'trafication' (cf. Sw. vinka 'wave'), inkkari (< Engl. Indian) and linkkari 'jackknife' (< Finn. linkkuveitsi). The means of manipulation are at least partly of Swedish origin.

In phonology and phonotactics, OHS has a peculiar mixture of Swedish and Finnish systems. The voiced stops, the sibilant $\check{s}$ and the affricate $t \check{s}$ are known in Swedish, but they are different from Finnish dialects. As with Swedish, OHS does not follow vowel harmony, which is a definite phonological restriction in Finnish, and it has a large repertoire of word-initial consonant clusters. All these properties apparently stem from Swedish, and they are deployed in lexical manipulation. On the other hand, vowel paradigm and the quantitative opposition of phonemes concur with the Finnish.

The Morpho-syntax of OHS agrees with (dialectal) Finnish, although there are some innovations in verb conjugation and questioning sentences. The roots of the innovations are in Finnish dialects, but they reflect the tendency to keep verb stems invariant. The slang suffixes may have been favoured for the same reason, since it is sometimes possible to avoid noun stem alteration by using them. This tendency may at least partly be triggered by Swedish, as in Swedish the stems barely alter. It is possible that some innovations, especially in verb declination, questioning sentences and object's case selection come from the 'broken' Finnish the Swedes spoke as their second language.

As contact-induced features are so common in OHS, bilingual Finnish and Swedish speakers apparently had a key role in its development. Although separate words may be borrowed even with very limited skill of source language, the mixture of OHS could not have emerged, if the first generation had not spoken both Finnish and Swedish at a relatively advanced level. And as bilingualism must have been - and we actually know it was - very common, it is only to be expected that code-switching played a role when OHS was born.

As far as we know, OHS mostly follows Finnish morpho-syntax, and Swedish words are inflected by Finnish grammar. There are still some examples where Swedish phrases (in boldface) are not embedded in the Finnish matrix, but they are used in a way which resembles code switching. In the example (33), there is a distinct Swedish phrase andra vooninki ( $<\mathrm{Sw}$. andra vaning) 'second floor', which is not inflected; the phrase is followed by the Finnish parallel toise-s kerrokse-s 'on the second floor', which is in the inessive case, according to Finnish grammar.

$\begin{array}{lllllll}\text { Ravintola } & \text { Kulma ol-i } & \text { siinä... } & \text { andra } & \text { vooninki, } & \text { toise-s } & \text { kerrokse-s } \\ \text { Restaurant } & \text { (name) } & \text { be-PAST.3SG there... } & \text { second floor } & \text { second-INE } & \text { floor-INE } \\ \text { 'Restaurant Kulma was there... on the second floor' } & & & \end{array}$

In the example (34), there is a Swedish phrase hela dagen 'all the day', which has regular Swedish definite suffixes. This phrase is common in OHS, and it is never inflected by Finnish grammar.

\begin{tabular}{|c|c|c|}
\hline $\begin{array}{l}\text { Tavallisesti } \\
\text { normally }\end{array}$ & $\begin{array}{l}\text { tveta-ttiin } \\
\text { wash-PASS }\end{array}$ & $\begin{array}{l}\text { hel-a } \\
\text { all-DEF }\end{array}$ \\
\hline
\end{tabular}

A parallel Swedish phrase, for example (35), could be sticka pa bollen. The verb stikka- $a$ has a Finnish infinitive ending here, and in the noun bolu there is Finnish spare vowel, but the noun is preceded by the Swedish preposition $p o<$ Sw. på. This sentence does not follow Finnish syntax, which would demand that the word bolu be in the illative case: *stikka-a bolu-un. 


$\begin{array}{lll}\text { stikka-a } \quad \text { po } & \text { bolu } \\ \text { hit-INF } & \text { PREP } & \text { 'ball' } \\ \text { 'to hit to the face' } & \end{array}$

Considering the fact that these sporadic notes are from 1976, it is very possible that code switching had been much more common earlier. It is tempting to assume that OHS has developed by frequent code-switching of Finnish and Swedish dialects, and it has thereafter developed into a mixed code, when Swedish phrases were more and more embedded in the Finnish matrix, i.e. speakers began to inflect Swedish words by applying the rules of Finnish grammar. As this mixed language was applied as an identity marker, the general idea of Finnish grammar and Swedish (or more precisely,Un-Finnish) vocabulary was elaborated and a parallel OHS lexicon was created. Words were adopted from different sources, and they were manipulated so that the new lexicon became more uniform and manifested marked differences from Finnish.

It is reasonable to assume, on historical and statistical grounds, that OHS had developed by both relexification and regrammaticalization, or by borrowing and language shift: Finnish speakers have adopted new vocabulary, and Swedish speakers have adopted Finnish grammar. These processes may have been concurrent, but it is also possible that OHS had first been created by relexification, and language shift from Swedish to OHS (and Finnish, as they have the same grammar) took place later. By its vocabulary, OHS is reminiscent of an early stage of learning Swedish as a second language; in morpho-syntax, there are some traces of Finnish as a second language.

As OHS bears an apparent resemblance to intertwined mixed languages, which have lexicon from one source and grammar from the other, it is justifiable to compare it with Media Lengua and Ma'a. Common to the three language forms is that they express group identity and show, at least to some extent, a negative attitude towards the ancestral group (cf. Bakker, 1996:19). In the case of OHS, the mixed language form expresses a new identity of the urban Finnish working class and manifests a strict difference from both the countrymen and the urban bourgeoisie.

Media Lengua and OHS are similar in a sense that their vocabulary is mostly from more prestigious 'outsider' languages; in Media Lengua from Spanish and in OHS from Swedish. In Media Lengua, a relexification process is apparent, and something rather similar may have happened in OHS. Furthermore, the sociolinguistic settings are comparable: both language forms were born in suburban areas, where immigrants came from the countryside and came into contact with the urban language. Nonetheless, Media Lengua seems to be more extreme: its vocabulary is almost exclusively from Spanish, while OHS vocabulary is more heterogeneous. It is feasible that OHS has more morpho-syntactical innovations than Media Lengua, which has maintained Quechuan morpho-syntax well. Furthermore, Media Lengua has Quechuan phonology, but OHS phonology has both Swedish and Finnish properties. A significant difference is that Media Lengua is apparently more established and independent, and 'language-like', than OHS. It also has native speakers, which is not the case with OHS.

Ma'á and OHS also have evident similarities. They both have heterogeneous vocabulary coming from different sources, and they manifest differences from their 'matrix languages' with lexical manipulation. In Ma'á, words can be derived from Normal Ma'á words by changing the final vowel and the tone pattern; in OHS, voiced stops and word-initial consonant clusters have a similar function. There are characteristic nominal endings for vocabulary in both languages: in Ma'á, they might be related to Cushitic plural suffixes, and in OHS, they are partly of Swedish origin. The two language forms are both symbiotic - Inner Ma’á with Normal Ma'á, OHS with Finnish - and they deploy two parallel vocabularies; the process by which they exist may be called paralexification.

In Mous (2001) some aspects of paralexification are presented that may be well applied to OHS. At first, he says that paralexification may particularly affect basic vocabulary (ib:122); as it was seen in section 4.1, a significant part of OHS's core vocabulary comes from Swedish. Secondly, 
after paralexification, words in the two parallel lexicons have identical "morphological properties", e.g. noun class properties (ib:114). In OHS, a similar phenomenon may be that Swedish words have same collocations as corresponding Finnish words. An example of this was Swedish adverbs messiand mella- in examples (9-12). The verbs hoppa- 'jump' and nubba 'drink' in examples (22) and (23) have exactly the same arguments as Finnish hypätä 'jump' and juoda 'drink'. Nonetheless, the point of constant 'inner form' is also presented by Muysken (1981:61) in his survey of Media Lengua, and thus relexification and paralexification are apparently similar in this sense.

On the other hand, there are also obvious differences between Ma'á and OHS. In the case of Ma'á, almost all members of the language community are bilingual, whereas only some Finnish speakers knew OHS even in Helsinki, not to mention the whole of Finland. Kallio (2007) points out that while children grew up in OHS speaking neighbourhoods, OHS could have been seen as their second native language, which was symbiotic with Finnish. It should still be remembered that OHS was never spoken in the whole community, even in working class areas, and women did not use it as commonly as men. Another significant difference is that the history of Ma'a does not resemble the history of OHS. Although there are several theories about the development of Ma'á, all scholars accept that it was originally a Cushitic language; that is to say, the original (hypothetical) Cushitic language lives on in Ma'á vocabulary. When applied to OHS, this would mean that OHS was originally a Swedish language, which is definitely not the case. And while the original Cushitic language has disappeared, both Swedish and Finnish are spoken in Helsinki even today. With their symbiotic mixed language form, Ma'á speakers uphold tradition and manifest resistance to total culture assimilation, but OHS speakers abandon tradition and manifest a new urban culture. In Ma'á, the vocabulary reflects conservatism; in OHS, it is innovative. But despite these differences in the historical and the sociocultural setting, Ma'á and OHS are linguistically very closely related. Both have parallel vocabularies, they exploit words from different sources and manipulate them in order to show a negative attitude towards their 'matrix languages'. Ma'á speakers want to differentiate themselves from a Bantu-speaking environment, and OHS speakers want to do the same in seeing themselves separate from rural Finnish spoken by newcomers and countrymen.

In conclusion, there are so many apparent similarities with OHS, Media Lengua and Ma'a that OHS might well be described as an intertwined mixed language. Of course, the status of OHS as a separate language might be questioned, because it apparently was never an independent or an established system. But this does not reduce its value as an example of language mixing in an exceptionally well-documented urban environment, even though the process was interrupted, as a balance between Swedish and Finnish was lost. In most cases, we have documents only of contemporary mixed languages, and hardly ever of their development and history. OHS shows us the first stages of language mixing, which, in most cases remain elusive for scholars today.

\section{References}

Bakker, Peter. 1996. Language intertwining and convergence: typological aspects of the genesis of mixed languages, in: Sprachtypologie und Universalienforschung 49:9-20. Berlin: Akademie-Verlag.

Coetzem, Frans van. 2000. A general and unified theory of the transmission process in language contact. Heidelberg: Winter.

Forsberg, Hannele. 1994. Havaintoja kysymystyypistä otat sie sä, in: Virittäjä 98:60-68. Helsinki: Kotikielen seura.

Forsskåhl, Mona. 2006. Helsinki slang around 1900: a new slang variety is born, in: Revue d'Études françaises 11:53-67. 
Höckerstedt, Leif. 2006. Helsingforssvenskan - vem är du? in: Juusela, K. \& Nisula, K. 2006 (eds.): Helsinki kieliyhteisönä, 123-141. Helsinki: Helsingin yliopiston suomen kielen ja kirjallisuuden laitos.

Kallio, Petri. 2007. How Uralic is Stadin Slangi? in: Blokland, R. \& Hasselblatt, C. (eds.), Language and Identity in the Finno-Ugric World, 176-191. Studia Fenno-Ugrica Groningana 4. Maastricht: Shaker.

McConvell, Patrick. \& Meakins, Felicity. 2005. Gurindji Kriol: A mixed language emerges from code-switching. Australian Journal of Linguistics 25:9-30.

Mous, Maarten. 1994. In Myers-Scotton 2002:266-270.

Mous, Maarten. 2001. Paralexification in language intertwining. In Smith, N. \& Veenstra, T. (eds.) Creolization and contact, 113-123. Creole Language Library 23. Amsterdam: Benjamins.

Mous, Maarten. 2003. The making of Mixed language. The case of Ma'á/Mbugu. Amsterdam: Benjamins.

Muysken, Pieter. 1981. Halfway between Spanish and Quechua: The case for relexification, in: Highfield, A. \& Valdman, A. (eds.) Historicity and variation in creole studies, 52-78. Ann Arbor: Karoma.

Myers-Scotton, Carol. 2002. Contact linguistics: bilingual encounters and grammatical outcomes. Oxford: University Press.

Nyholm, Leif \& al., 1989. Helsingforsslang nu, en skolenkät 1988. Meddelanden från institutionen för nordiska språk och litteratur vid Helsingfors universitet B: 12. Helsinki: Yliopistopaino.

Paunonen, Heikki. 1995. Suomen kieli Helsingissä. Huomioita Helsingin puhekielen historiallisesta taustasta ja nykyvariaatiosta. Helsinki: Helsingin yliopiston suomen kielen laitos.

Paunonen, Heikki. 2000. Tsennaaks Stadii, bonjaaks slangii. Stadin slangin suursanakirja. Helsinki: Werner Söderström.

Paunonen, Heikki. 2006. Vähemmistökielestä varioivaksi valtakieleksi, in: Juusela, K. \& Nisula, K. (eds.): Helsinki kieliyhteisönä, 13-99. Helsinki: Helsingin yliopiston suomen kielen ja kirjallisuuden laitos.

Saari, Mirja. 2006. Stadin ruotsi. Huomioita erään nuorisoryhmän koodin vaihtelusta, in: Juusela, K. \& Nisula, K. (eds.): Helsinki kieliyhteisönä, 142-161. Helsinki: Helsingin yliopiston suomen kielen ja kirjallisuuden laitos.

Sorsakivi, Merja. 1982. Infinitiivimuutoksia lasten kielessä, in: Virittäjä 86:377-391. Helsinki: Kotikielen seura.

Thomason, Sarah \& Kaufman, Terrence. 1988. Language contact, creolization, and genetic linguistics. Berkeley: University of California Press.

Thomason, S 2001. Contact-induced typological change, in: Haspelmath, M. \& Koenig, E. \& Oesterreicher, W \& Raible, W. (eds.): Language typology and language universals: An international handbook, 1640-1648. Berlin \& New York: Walter de Gruyter.

Wälchli, Bernard 2005. Relexicalization vs. Relexification: the case of Stadin Slangi Finnish. Unpublished paper. 